\title{
A Split Luciferase Complementation Assay for the Quantification of $\beta$-Arrestin2 Recruitment to Dopamine $\mathrm{D}_{2}$-Like Receptors
}

\author{
Lisa Forster *(1), Lukas Grätz ${ }^{\circledR}$, Denise Mönnich, Günther Bernhardt and Steffen Pockes *(1) \\ Institute of Pharmacy, University of Regensburg, D-93053 Regensburg, Germany; lukas.graetz@ur.de (L.G.); \\ denise.moennich@ur.de (D.M.); guenther.bernhardt@ur.de (G.B.) \\ * Correspondence: lisa.forster@ur.de (L.F.); steffen.pockes@ur.de (S.P.); \\ Tel.: +49-941-943-4796 (L.F.); +49-941-943-4825 (S.P.)
}

Received: 14 July 2020; Accepted: 21 August 2020; Published: 24 August 2020

\begin{abstract}
Investigations on functional selectivity of GPCR ligands have become increasingly important to identify compounds with a potentially more beneficial side effect profile. In order to discriminate between individual signaling pathways, the determination of $\beta$-arrestin 2 recruitment, in addition to G-protein activation, is of great value. In this study, we established a sensitive split luciferase-based assay with the ability to quantify $\beta$-arrestin 2 recruitment to $D_{2 l o n g}$ and $D_{3}$ receptors and measure time-resolved $\beta$-arrestin2 recruitment to the $D_{2 l o n g}$ receptor after agonist stimulation. We were able to characterize several standard (inverse) agonists as well as antagonists at the $D_{2 l o n g} R$ and $D_{3} R$ subtypes, whereas for the $D_{4.4} R$, no $\beta$-arrestin 2 recruitment was detected, confirming previous reports. Extensive radioligand binding studies and comparisons with the respective wild-type receptors confirm that the attachment of the Emerald luciferase fragment to the receptors does not affect the integrity of the receptor proteins. Studies on the involvement of GRK2/3 and PKC on the $\beta$-arrestin recruitment to the $D_{2 l o n g} R$ and $D_{3} R$, as well as at the $D_{1} R$ using different kinase inhibitors, showed that the assay could also contribute to the elucidation of signaling mechanisms. Its broad applicability, which provides concentration-dependent and kinetic information on receptor/ $\beta$-arrestin 2 interactions, renders this homogeneous assay a valuable method for the identification of biased agonists.
\end{abstract}

Keywords: GPCR; dopamine $D_{2}$-like receptors; $\beta$-arrestin; GRK; Emerald luciferase; functional assay

\section{Introduction}

The neurotransmitter dopamine exerts its effects via five dopamine receptor (DR) subtypes $\left(D_{1}, D_{2}, D_{3}, D_{4}\right.$ and $\left.D_{5}\right)$, which are all members of the superfamily of G-protein-coupled receptors (GPCRs) [1-5]. The family of dopamine receptors are classified into $D_{1}$-like receptors $\left(D_{1}\right.$ and $\left.D_{5}\right)$ and $\mathrm{D}_{2}$-like receptors $\left(\mathrm{D}_{2}, \mathrm{D}_{3}\right.$ and $\left.\mathrm{D}_{4}\right)$ according to their preferred G-protein signaling [6]. While $\mathrm{D}_{1}$-like receptors predominantly couple to $\mathrm{G} \alpha_{\mathrm{s} / \mathrm{olf}}$ proteins and stimulate the adenylyl cyclase (AC), thus increasing the intracellular cAMP level [7], $\mathrm{D}_{2}$-like receptors associate with $\mathrm{G} \alpha_{\mathrm{i} / \mathrm{o}}$ proteins, inhibiting the formation of cAMP [8-10]. Dopamine receptors are targeted by a variety of pharmacological agents since anomalous dopamine receptor signaling is implicated in numerous neuropsychiatric disorders in the human body such as schizophrenia [11], Parkinson's disease [12,13], drug addiction [14,15], genetic hypertension [16], bipolar disorder [17,18] and restless legs syndrome [19,20].

Apart from G-protein-mediated signaling, many GPCRs are known to recruit $\beta$-arrestin, which is involved in receptor desensitization, internalization processes and also in signaling ( $\beta$-arrestin-dependent signaling) [21-23]. It is generally accepted that phosphorylation of GPCRs by G-protein receptor kinases (GRKs) or protein kinase C (PKC) at specific clusters of serine and 
threonine residues located in the receptor C-terminus precedes $\beta$-arrestin binding [21,24-26]. However, $\beta$-arrestin recruitment to agonist-activated non-phosphorylated receptors has also been described, but with lower affinity [21]. Furthermore, $\beta$-arrestins also participate in receptor sequestration and play a role in desensitization and subsequent resensitization of GPCR responsiveness [22]. The most abundantly expressed arrestins in mammals are $\beta$-arrestin1 and $\beta$-arrestin2 [27]. Based on their binding preference towards $\beta$-arrestins and their behavior during the internalization, GPCRs can be subdivided in two major classes (class A and B) [28]. A precise classification of the respective dopamine receptors according to this model is very difficult due to the complexity of available data [29,30]. However, in terms of $D_{2}$-like receptors, the $D_{2} R$ and the $D_{3} R$ are frequently described to be phosphorylated by GRKs, resulting in the recruitment of $\beta$-arrestins [31-34], while no recruitment is described for the $D_{4} R[35,36]$. The $D_{2}$ and $D_{3}$ receptors share a high sequence homology [37] but are regulated differently and show different levels of basal phosphorylation [33,34,38].

In current drug development of antipsychotics, the need for biased ligands to reduce adverse drug effects is the subject of lively debate. A study by Masri et al. led to the assumption that functionally selective $D_{2}$ receptor antagonists, specifically preventing $\beta$-arrestin2 recruitment may lead to new antipsychotics with reduced extrapyramidal side effects, while retaining their therapeutic benefit [39]. Therefore, the functional characterization of potential future drug candidates, with respect to $\beta$-arrestin2 recruitment, is of high relevance particularly in the very early stage of in vitro testing. Different assay techniques have been described for investigating $\beta$-arrestin2 recruitment in live cells. Commercially available split reporter assays currently used for high throughput screening do not give temporal information about the receptor/ $\beta$-arrestin interaction, since they require cell lysis [40] or real-time measurements are hampered by relatively long maturation times of the reporter protein (Venus, a variant of yellow fluorescent protein) [41]. A $\beta$-arrestin recruitment assay utilizing a transcription factor is the TANGO assay. Here, $\beta$-arrestin is fused to a protease, while a transcription factor, which is able to induce transcription of $\beta$-lactamase, is C-terminally attached to the receptor via a linker containing the respective protease cleavage sequence. Once $\beta$-arrestin gets recruited, the transcription factor is cleaved off, translocated into the nucleus and $\beta$-lactamase is expressed. For detection, a substrate is added and the cells need to be lysed [42]. Another approach for the quantification of $\beta$-arrestin recruitment to GPCRs is the LinkLight assay using a permuted luciferase reporter [43]. Here the GPCR of interest is fused to a viral protease and $\beta$-arrestin is fused to a permuted firefly luciferase containing a protease cleavage sequence. After arrestin recruitment, the permuted luciferase is cleaved and reconstituted to an active enzyme [43]. In transcription-based assays, the obtained signal is prone to amplification and no kinetic information can be gained from this experimental setup. Additionally, there are optimized luciferases available now that show a higher luminescence output and $\mathrm{pH}$ independence of the spectra [44]. We aimed to develop a $\beta$-arrestin recruitment assay that overcomes the aforementioned limitations, and the split Emerald luciferase complementation technique, first described by Misawa et al. [45], seemed to be appropriate. The employed Emerald luciferase (ELuc) was cleaved into two fragments of which the $\mathrm{N}$-terminal part was fused to $\beta$-arrestin2 (referred to as ELucN- $\beta$-arr2) and the C-terminal part to the respective receptor (Figure 1).

The ability to perform measurements in living cells allows one to retrieve kinetic information about protein-protein interactions $[40,46]$. Additionally, the utilized ELuc results in improved sensitivity of the test system, as the signal brightness is increased compared to commercially available test kits [45]. Moreover, this homogeneous assay can be conducted very rapidly without the necessity for any washing or separation step, facilitating the development of high-throughput screening campaigns [45]. To investigate the responses of the $D_{2}$-like receptors upon agonist stimulation, a $\beta$-arrestin recruitment assay, based on the split luciferase complementation technique, was established in this study and is described as follows. 


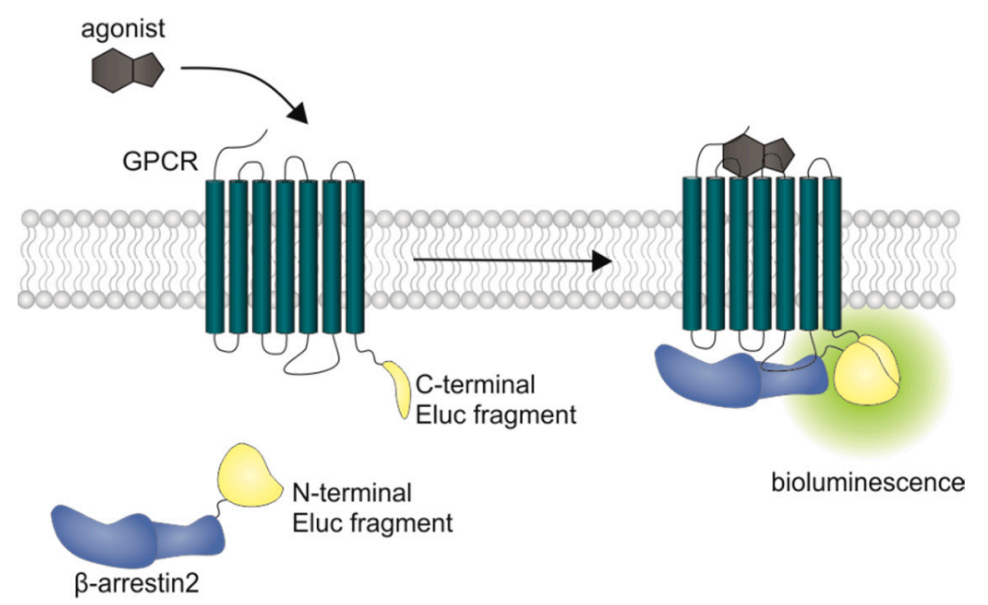

Figure 1. Schematic illustration of the split luciferase $\beta$-arrestin 2 recruitment assay. Complementary fragments of the Emerald luciferase were fused to $\beta$-arrestin 2 and the $D_{1} R$, the $D_{2 l o n g} R$, the $D_{3} R$ or the $D_{4.4} R$. Upon agonist stimulation of the receptor, $\beta$-arrestin 2 is recruited and the luciferase fragments come into close proximity to form a functional enzyme, which catalyzes the oxidation of D-luciferin to oxyluciferin, accompanied by the emission of light $\left(\lambda_{\max }=535 \mathrm{~nm}\right)$.

\section{Results and Discussion}

\subsection{Characterization of the Receptor Fusion Proteins}

To verify the membrane expression of the receptor-luciferase fusion constructs and to investigate a potential influence of the receptor modification on ligand affinities, radioligand saturation binding experiments were performed with the radiolabeled antagonist $\left[{ }^{3} \mathrm{H}\right] \mathrm{N}$-methylspiperone at the generated $\mathrm{D}_{2}$-like receptor constructs. Saturable binding (Figure S1, Supplementary Materials) was found for all of them and the $\mathrm{p} K_{\mathrm{d}}$ values of $10.56\left(\mathrm{D}_{2 \text { long }} \mathrm{R}\right.$-ELucC), $10.31\left(\mathrm{D}_{3} \mathrm{R}\right.$-ELucC) and $9.40\left(\mathrm{D}_{4.4} \mathrm{R}\right.$-ELucC) at the respective receptor fusion protein were in good agreement with $\mathrm{p} K_{\mathrm{d}}$ values determined at receptors devoid of the luciferase fragment (subsequently referred to as wild-type, cf. Methods) (Table 1 and Figure S1, Supplementary Materials). This confirms that the fusion of the luciferase fragment to the respective receptor did not markedly impair the affinity to the ligand.

Table 1. Dissociation constants ( $\mathrm{p} K_{\mathrm{d}}$ values) of $\left[{ }^{3} \mathrm{H}\right] N$-methylspiperone determined in radioligand saturation binding experiments at receptors fused to the $\mathrm{C}$-terminal fragment of the Emerald luciferase using whole cells and at wild-type receptors using homogenates. Data represent means \pm SEM determined in three independent experiments, each performed in triplicate.

\begin{tabular}{ccccccc}
\hline & \multicolumn{2}{c}{$\mathbf{D}_{\text {2long }} \mathbf{R}$} & \multicolumn{2}{c}{$\mathbf{D}_{3} \mathbf{R}$} & \multicolumn{2}{c}{$\mathbf{D}_{4.4} \mathbf{R}$} \\
\cline { 2 - 8 } & $\begin{array}{l}\text { ELucC } \\
\text { Fusion } \\
\text { Protein }\end{array}$ & wt & $\begin{array}{l}\text { ELucC } \\
\text { Fusion } \\
\text { Protein }\end{array}$ & wt & ELucC & Fusion \\
Protein & wt \\
\hline $\mathrm{pK}_{\mathrm{d}}$ & $10.56 \pm 0.04$ & $10.84 \pm 0.05$ & $10.31 \pm 0.03$ & $10.59 \pm 0.01$ & $9.40 \pm 0.09$ & $10.11 \pm 0.04$ \\
\hline
\end{tabular}

The results from radioligand displacement experiments at the receptor-ELucC constructs, which were compared with the results obtained at the wild-type receptors (Table 2) supported this finding. At all three investigated dopamine receptor subtypes, the $\mathrm{p} K_{\mathrm{i}}$ values of the tested antagonists haloperidol and nemonapride determined at the receptor fusion proteins correspond very well with the affinities determined at wild-type receptors. In the case of the agonist quinpirole and the partial agonist aripiprazole, slight discrepancies but no general pattern was identified. With a $\mathrm{p} K_{\mathrm{i}}$ of 9.25 compared to 8.32 , aripiprazole showed a higher affinity to the $\mathrm{D}_{2 \text { long }} \mathrm{R}$-ELucC fusion protein than to the wild-type receptor (Table 2). The same observations were made for aripiprazole at the $\mathrm{D}_{3} \mathrm{R}$ with a 
$\mathrm{p} K_{\mathrm{i}}$ value of 8.9 at the ELucC construct compared to 7.85 at the wild-type receptor (Table 2). However, the data for the $\mathrm{D}_{4.4} \mathrm{R}$-ELucC and the wild-type $\mathrm{D}_{4.4} \mathrm{R}$ were in very good agreement with each other. For quinpirole, a biphasic displacement curve was observed at the wild-type $\mathrm{D}_{2 \text { long }} \mathrm{R}$, yielding a highand a low-affinity inhibition constant (Table 2), which is in line with published data [47]. By contrast, a monophasic displacement curve was obtained at the ELucC fusion protein with a $\mathrm{p} K_{\mathrm{i}}$ value that was in between the high- and low-affinity inhibition constant determined at the wild-type $\mathrm{D}_{2 \text { long }} \mathrm{R}$ (Table 2). At the $\mathrm{D}_{3} \mathrm{R}$ and the $\mathrm{D}_{4.4} \mathrm{R}$, only monophasic displacement curves could be fitted. For both receptors, quinpirole showed a higher affinity to the wild-type receptor. It is known that the use of whole cells has a significant influence, especially on the determination of agonist affinities [48]. Since the binding experiments on the fusion proteins were carried out with whole cells, this could be the reason for the differences rather than the fusion of the luciferase fragment to the C-terminus of the receptor.

Table 2. Inhibition constants $\left(\mathrm{p} K_{\mathrm{i}}\right)$ of selected standard ligands determined in radioligand displacement experiments. $\mathrm{p} K_{\mathrm{i}}$ values were determined at receptors fused to the $\mathrm{C}$-terminal fragment of the Emerald luciferase using whole cells and at wild-type receptors using homogenates. Data represent mean $\mathrm{p} K_{\mathrm{i}} \pm$ SEM determined in three independent experiments, each performed in triplicate.

\begin{tabular}{|c|c|c|c|c|c|c|c|}
\hline \multirow[b]{2}{*}{ cpd } & \multicolumn{3}{|c|}{$\mathrm{D}_{\text {2long }} \mathrm{R}$} & \multicolumn{2}{|c|}{$\mathrm{D}_{3} \mathrm{R}$} & \multicolumn{2}{|c|}{$\mathrm{D}_{4.4} \mathrm{R}$} \\
\hline & $\begin{array}{l}\text { ELucC } \\
\text { Fusion } \\
\text { Protein }\end{array}$ & & wt & $\begin{array}{l}\text { ELucC } \\
\text { Fusion } \\
\text { Protein }\end{array}$ & wt & $\begin{array}{l}\text { ELucC } \\
\text { Fusion } \\
\text { Protein }\end{array}$ & wt \\
\hline aripiprazole & $9.25 \pm 0.16$ & & $8.32 \pm 0.02$ & $8.9 \pm 0.24$ & $7.85 \pm 0.08$ & $7.64 \pm 0.15$ & $7.85 \pm 0.08$ \\
\hline quinpirole & $7.29 \pm 0.07$ & $\begin{array}{l}\text { hi } \\
\text { lo }\end{array}$ & $\begin{array}{l}7.90 \pm 0.10 \\
6.11 \pm 0.02\end{array}$ & $7.63 \pm 0.05$ & $8.00 \pm 0.08$ & $6.58 \pm 0.01$ & $8.00 \pm 0.08$ \\
\hline $\begin{array}{l}\text { haloperidol } \\
\text { nemonapride }\end{array}$ & $\begin{array}{l}9.45 \pm 0.05 \\
9.95 \pm 0.13\end{array}$ & & $\begin{array}{l}9.58 \pm 0.13 \\
9.76 \pm 0.08\end{array}$ & $\begin{array}{l}8.27 \pm 0.08 \\
9.76 \pm 0.06\end{array}$ & $\begin{array}{l}8.93 \pm 0.02 \\
9.33 \pm 0.02\end{array}$ & $\begin{array}{l}8.27 \pm 0.02 \\
9.69 \pm 0.08\end{array}$ & $\begin{array}{l}8.93 \pm 0.02 \\
9.33 \pm 0.02\end{array}$ \\
\hline
\end{tabular}

Aiming at the development of an assay, that not only allows the measurement of reliable potencies and efficacies but also offers the possibility to conduct live cell measurements as well as kinetic observations of $\beta$-arrestin2 recruitment, each transfectant was tested for the feasibility of a real-time experiment. The $\mathrm{D}_{2 \text { long }} \mathrm{R}$-ELucC expressing cells showed robust concentration-dependent responses with high signal-to-background (S/B) ratios to stimulation with different agonists when the substrate D-luciferin was added to live cells (Figure 2). As we used the area under the curve (AUC) for the analyses of the data from the $\beta$-arrestin2 recruitment assays, no quantitative correlation between the intrinsic activity and the $\mathrm{S} / \mathrm{B}$ ratio could be made apart from classifying the ligand as a full/partial agonist. Unfortunately, live-cell measurements at HEK293T cells expressing the $\mathrm{D}_{3} \mathrm{R}$-ELucC showed no $\beta$-arrestin 2 recruitment. It was previously reported that the $D_{3} R$ only recruits $\beta$-arrestin 2 to a very small extent [33], but by performing lysis-based measurements, reliable results with reasonable $\mathrm{S} / \mathrm{B}$ ratios (Figure 2) after stimulation with various agonists were obtained. As expected, data correlate with the respective $E_{\max }$ values of the tested agonists. In consistency with published data [35], the cells expressing the $\mathrm{D}_{4.4} \mathrm{R}$ did not show any response to agonistic stimulation in either real-time or lytic endpoint measurements. 


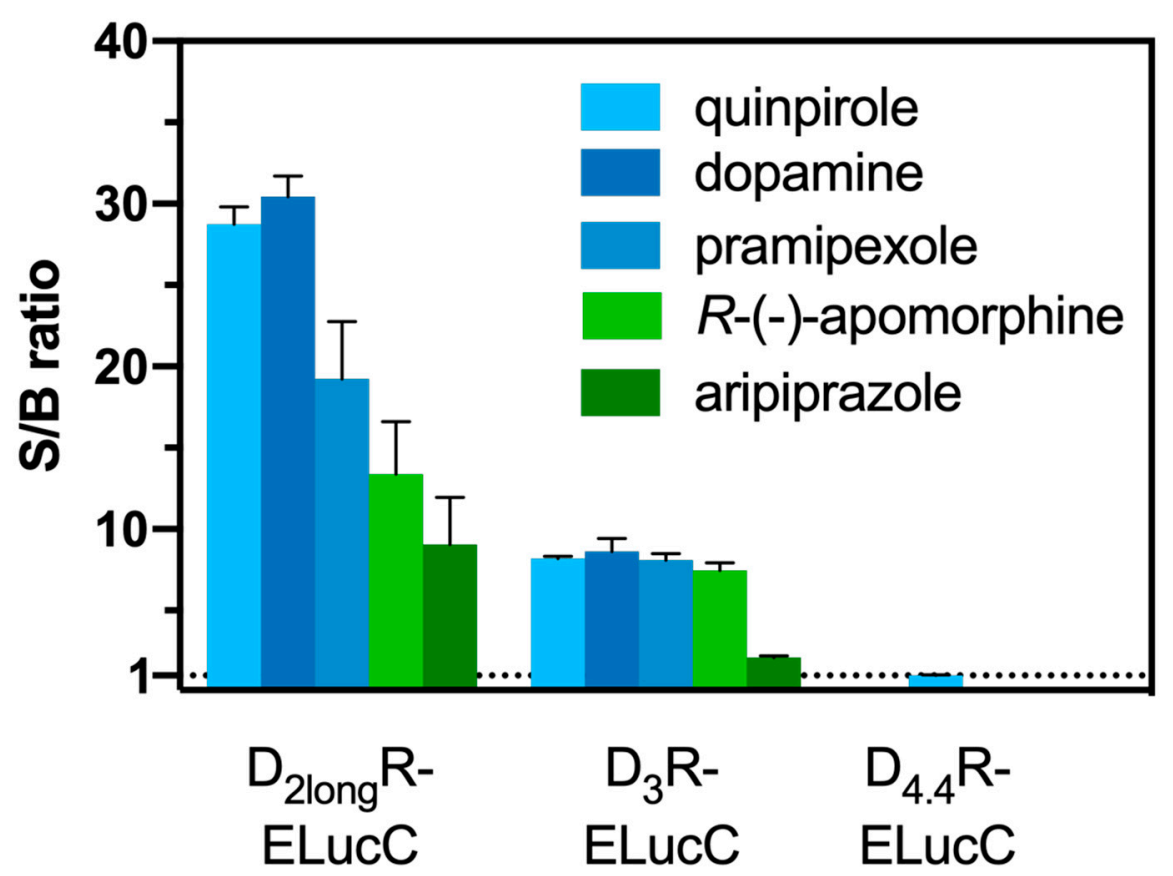

Figure 2. S/B ratios of the complemented ELuc after agonistic stimulation of the analyzed receptors. The cells were stimulated with various agonists (concentration corresponding to the estimated $\mathrm{EC}_{80}$ value) and in case of the $\mathrm{D}_{2 \text { long }} \mathrm{R}$ the resulting AUC after $50 \mathrm{~min}$ was divided by the area obtained from a solvent control. S/B ratios of the $\mathrm{D}_{3} \mathrm{R}$ and the $\mathrm{D}_{4.4} \mathrm{R}$ were retrieved by dividing the luminescence after $90 \mathrm{~min}$ by that of a solvent control. Data represent means \pm SEM from at least three independent experiments performed in triplicate.

\subsection{Pharmacological Characterization of Dopamine Receptor Ligands in the $\beta$-Arrestin2 Split Luciferase} Complementation Assay

Standard agonists and antagonists were tested to explore the suitability of the $\beta$-arrestin 2 split luciferase complementation assay to pharmacologically characterize dopamine receptor ligands of different qualities of action, regarding their potencies $\left(\mathrm{pEC}_{50}\right)$, efficacies $\left(\mathrm{E}_{\max }\right)$ or antagonistic activities $\left(\mathrm{p} K_{\mathrm{b}}\right)$. As agonists, the endogenous ligand dopamine, as well as pramipexole, a widely used drug for the treatment of Parkinson's disease, and the full agonist quinpirole, were chosen. With $R$-(-)-apomorphine and aripiprazole, a "third generation" antipsychotic drug, exhibiting a unique activity profile, two partial agonists were included in the study as well $[49,50]$. For defining the efficacy of each compound at the respective receptor, quinpirole was set as the reference agonist $(100 \%)$, since it shows a higher chemical stability with respect to oxidation compared to the endogenous ligand dopamine.

All agonists showed a time-dependent increase in luminescence in a concentration-dependent manner, which could be converted to concentration-response curves (Figures 3 and $4 \mathrm{~A}$ ). The $\mathrm{pEC}_{50}$ values for all agonists determined at the $\mathrm{D}_{\text {2long }} \mathrm{R}$ (Table 3 ) were in very good agreement with data reported in the literature derived from commonly used assays such as $\left.{ }^{35} \mathrm{~S}\right] \mathrm{GTP} \gamma \mathrm{S}$ binding [49] or cAMP assays [51], not differing more than 0.5 orders of magnitude. The endogenous ligand dopamine exhibited full intrinsic activity in the experiment, whereas pramipexole was only able to elicit $86 \%$ of the maximal response induced by quinpirole (Table 3). It was previously reported that pramipexole acts as a partial agonist at the dopamine $\mathrm{D}_{2 \text { long }} \mathrm{R}$ [52]. Aripiprazole appeared as a partial agonist in recruiting $\beta$-arrestin2 to the $D_{2 l o n g} R$ with a very low intrinsic activity $\left(E_{\max }=8 \pm 2 \%\right.$ ) (Table 3 ). The efficacy of aripiprazole at the $\mathrm{D}_{2 \text { long }} \mathrm{R}$ is controversial, with publications claiming that it is an antagonist regarding $\beta$-arrestin2 recruitment [39] and others describing it as a partial agonist in recruiting $\beta$-arrestin2 with efficacies ranging from $47 \%$ to $73 \%$ depending on the assay [50]. $R$-(-)-apomorphine is reportedly a partial agonist, which we confirmed in our assay with an efficacy of $87 \%$ (Table 3 ). This fits very well 
with already published data [52]. For the $\mathrm{D}_{3} \mathrm{R}$, the potencies of all agonistic compounds (Figure $4 \mathrm{~A}$ ) also correlate very well with published data. Dopamine and pramipexole acted as full agonists, whereas $R$-(-)-apomorphine and aripiprazole showed $E_{\max }$ values of $91 \%$ and $26 \%$, respectively (Table 3). For both compounds, a partial agonism at the $\mathrm{D}_{3} \mathrm{R}$ has been described elsewhere $[49,53]$, with efficacies in a comparable range.
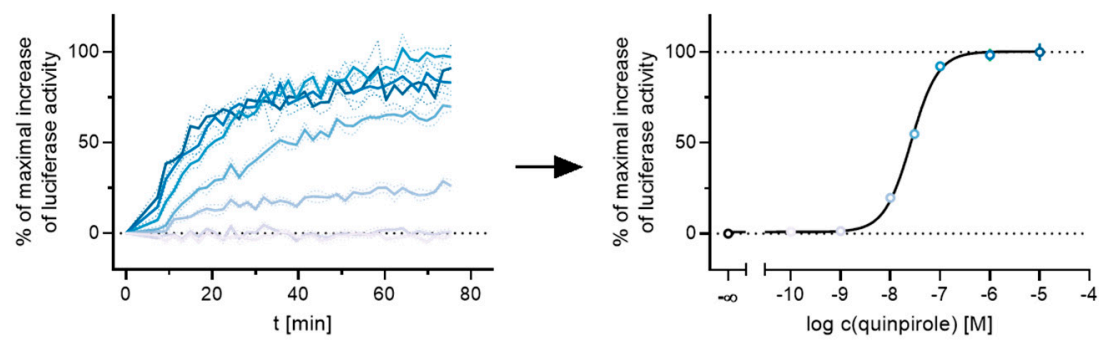

Figure 3. Exemplary results of a live-cell measurement at the $D_{2 l o n g} R$. HEK293T cells stably expressing ELucN- $\beta$ arr2 and $\mathrm{D}_{2 \text { long }} \mathrm{R}$-ELucC were stimulated with different concentrations of the standard agonist quinpirole. The time-dependent increase in luminescence was recorded and the AUC after 50 min was used to generate a concentration-response curve.

\section{A}

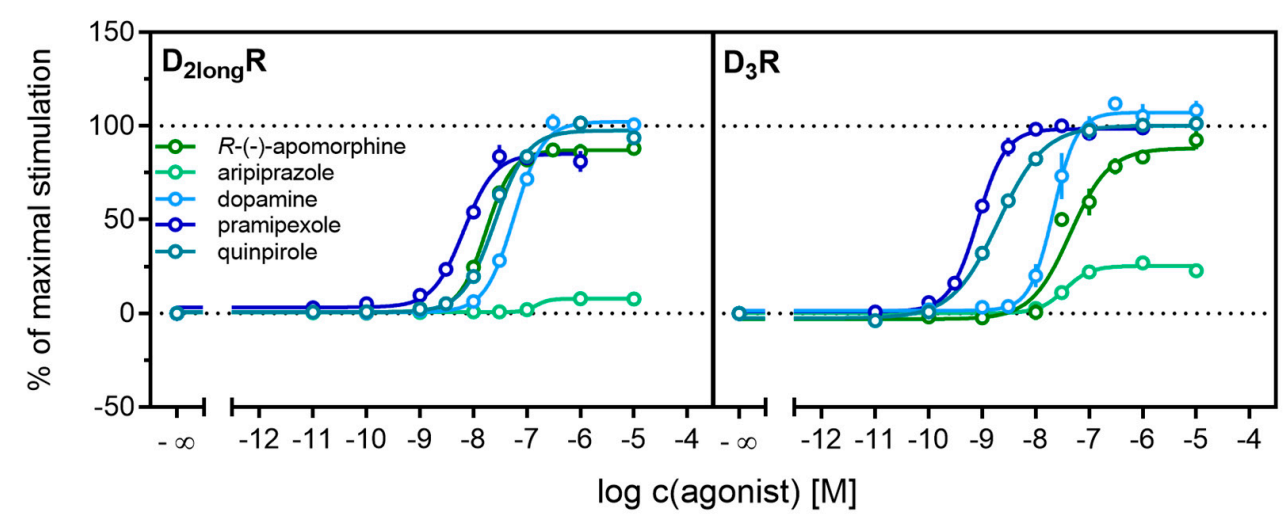

B

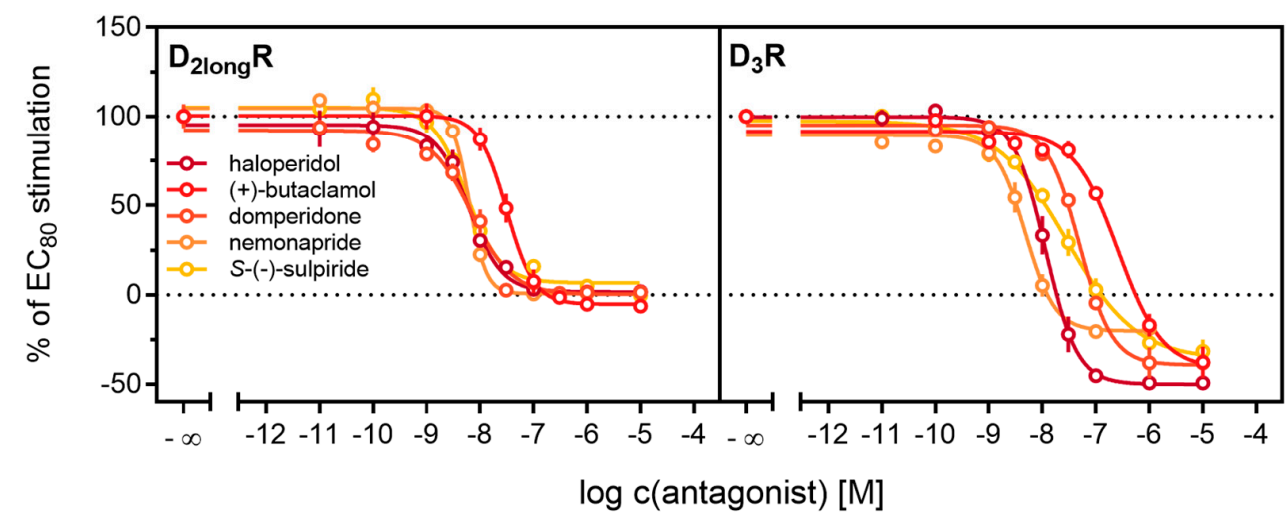

Figure 4. Characterization of standard ligands in the $\beta$-arrestin2 recruitment assay. A set of agonists (A) and antagonists (B) were tested for their ability to promote or inhibit (the quinpirole-induced) $\beta$-arrestin recruitment at the $D_{2 l o n g} R$ and the $D_{3} R$. Data of agonists were normalized to the maximal stimulation induced by $1 \mu \mathrm{M}$ quinpirole $(100 \%)$ and a solvent control $(0 \%)$. Antagonist data were normalized to the signal elicited by quinpirole at a concentration corresponding to the $\mathrm{EC}_{80}(100 \%)$ and a solvent control $(0 \%)$. Obtained $\mathrm{pEC}_{50}, \mathrm{E}_{\max }$ and $\mathrm{pK}_{\mathrm{b}}$ values are presented in Table 2. Data represent means \pm SEM from at least three independent experiments, each performed in triplicate. 
Antagonistic activities $\left(\mathrm{p} K_{\mathrm{b}}\right)$ of (+)-butaclamol, domperidone, haloperidol and nemonapride at the $\mathrm{D}_{2 \text { long }} \mathrm{R}$ (Figure $4 \mathrm{~B}$ ) also correlated very well with data described in the literature (Table 3), with the minor exception of $S-(-)$-sulpiride. The same generally applies to the $\mathrm{D}_{3} \mathrm{R}$ (Figure $4 \mathrm{~B}$ ), with nemonapride and (+)-butaclamol showing slight differences (Table 3). A constitutive interaction of the $D_{3} R$ with $\beta$-arrestin has been repeatedly reported $[37,54]$, which we also observed in our assay, as all antagonists were capable of lowering the arrestin-dependent luminescence signal at the $\mathrm{D}_{3} \mathrm{R}$ below the baseline. Therefore, the set of antagonists was also tested for inverse agonism in the developed assay (agonist mode) as shown in Figure 5. All these ligands exhibited negative efficacy at the $D_{3} R$ and potencies, which were comparable with the respective $\mathrm{p} K_{\mathrm{b}}$ values (Table 3 ).

Table 3. $\mathrm{pEC}_{50}, \mathrm{E}_{\max }$ and $\mathrm{p} K_{\mathrm{b}}$ values of standard compounds analyzed in the newly developed $\beta$-arrestin2 recruitment assay. For comparison, $\mathrm{p} K_{\mathrm{i}}$ values determined in radioligand displacement studies utilizing homogenates from HEK293T cells stably expressing the wild-type receptors (cf. Table 2) and published data from different assays are included. Data represent means $\pm \mathrm{SEM}$ from $\mathrm{N}$ independent experiments, each performed in triplicate.

\begin{tabular}{|c|c|c|c|c|c|c|c|c|}
\hline \multirow[t]{2}{*}{ Receptor } & \multirow[t]{2}{*}{ cpd } & \multicolumn{3}{|c|}{$\beta$-Arrestin2 Recruitment } & \multirow[t]{2}{*}{$\mathbf{N}$} & & \multirow{2}{*}{$\begin{array}{c}\begin{array}{l}\text { Radioligand } \\
\text { Displacement }\end{array} \\
\mathrm{p} K_{\mathrm{i}} \\
\end{array}$} & \multirow[t]{2}{*}{ Ref. } \\
\hline & & $\mathrm{pEC}_{50}$ & $\mathrm{E}_{\max }[\%]$ & $\mathrm{p} K_{\mathrm{b}}$ & & & & \\
\hline \multirow[t]{13}{*}{$\mathbf{D}_{\text {2long }} \mathrm{R}$} & $R$-(-)-apomorphine & $7.77 \pm 0.04$ & $87 \pm 3$ & & 4 & & $7.48 \pm 0.14$ & $7.66[49]$ \\
\hline & aripiprazole & $6.65 \pm 0.15$ & $8 \pm 2$ & & 3 & & $8.32 \pm 0.02$ & $6.84[50]$ \\
\hline & dopamine & $7.24 \pm 0.04$ & $104 \pm 3$ & & 3 & hi & $7.99 \pm 0.16$ & $7.05[55]$ \\
\hline & & & & & & lo & $6.30 \pm 0.07$ & \\
\hline & pramipexole & $8.19 \pm 0.05$ & $86 \pm 4$ & & 4 & hi & $7.59 \pm 0.12$ & $8.51[56]$ \\
\hline & & & & & & lo & $6.00 \pm 0.03$ & \\
\hline & quinpirole & $7.55 \pm 0.07$ & 100 & & 5 & hi & $7.90 \pm 0.10$ & $7.11[51]$ \\
\hline & & & & & & lo & $6.11 \pm 0.02$ & \\
\hline & (+)-butaclamol & & & $8.29 \pm 0.10$ & 3 & & $9.14 \pm 0.06$ & $8.04[57]$ \\
\hline & domperidone & & & $9.13 \pm 0.09$ & 3 & & $9.47 \pm 0.07$ & $8.87[58]$ \\
\hline & haloperidol & & & $8.90 \pm 0.05$ & 3 & & $9.58 \pm 0.13$ & 8.89 [59] \\
\hline & nemonapride & & & $8.90 \pm 0.05$ & 3 & & $9.76 \pm 0.08$ & $9.32[60]$ \\
\hline & $S$-(-)-sulpiride & & & $8.86 \pm 0.10$ & 3 & & $7.51 \pm 0.09$ & $8.22[61]$ \\
\hline \multirow[t]{11}{*}{$\mathrm{D}_{3} \mathrm{R}$} & $R$-(-)-apomorphine & $7.43 \pm 0.17$ & $91 \pm 5$ & & 3 & & $8.40 \pm 0.03$ & $7.93[49]$ \\
\hline & aripiprazole & $7.44 \pm 0.05$ & $26 \pm 1$ & & 3 & & $8.26 \pm 0.02$ & $7.00[62]$ \\
\hline & dopamine & $7.66 \pm 0.14$ & $105 \pm 8$ & & 3 & hi & $8.78 \pm 0.09$ & $7.95[63]$ \\
\hline & & & & & & lo & $7.23 \pm 0.09$ & \\
\hline & pramipexole & $9.09 \pm 0.06$ & $99 \pm 4$ & & 4 & & $9.18 \pm 0.06$ & 8.65 [49] \\
\hline & quinpirole & $8.75 \pm 0.07$ & 100 & & 6 & & $8.34 \pm 0.07$ & $9.07[56]$ \\
\hline & (+)-butaclamol & $7.16 \pm 0.17$ & $-27 \pm 9$ & $7.35 \pm 0.08$ & $3 / 3$ & & $8.59 \pm 0.02$ & $7.95[64]$ \\
\hline & domperidone & $8.02 \pm 0.14$ & $-26 \pm 4$ & $8.06 \pm 0.09$ & $3 / 3$ & & $8.96 \pm 0.11$ & $8.12[58]$ \\
\hline & haloperidol & $8.29 \pm 0.29$ & $-27 \pm 5$ & $8.68 \pm 0.12$ & $3 / 3$ & & $8.95 \pm 0.03$ & $8.70[65]$ \\
\hline & nemonapride & $8.43 \pm 0.13$ & $-25 \pm 4$ & $9.07 \pm 0.12$ & $3 / 3$ & & $9.99 \pm 0.06$ & $9.77[66]$ \\
\hline & $S$-(-)-sulpiride & $8.33 \pm 0.10$ & $-26 \pm 8$ & $8.23 \pm 0.07$ & $3 / 4$ & & $7.20 \pm 0.03$ & $7.70[58]$ \\
\hline
\end{tabular}

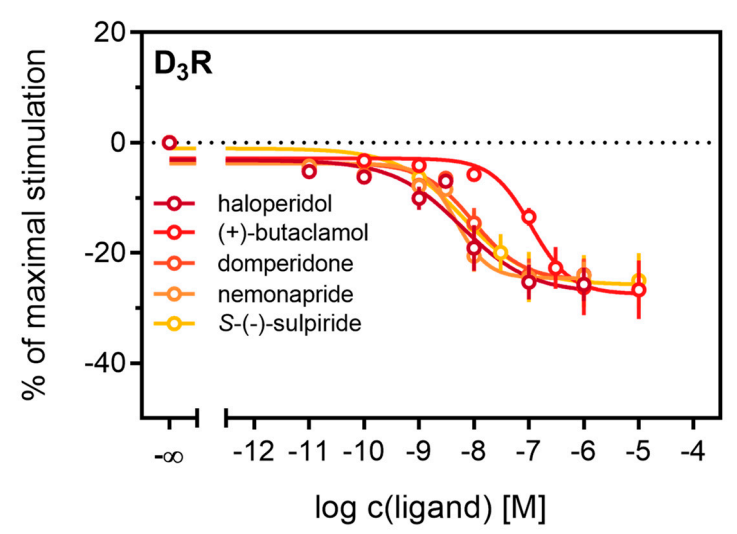

Figure 5. Detection of inverse agonism at the $D_{3} R$. Inhibition of constitutive $\beta$-arrestin 2 recruitment to the $D_{3} R$ by shown $D_{3} R$ ligands. Results are presented as percent maximal stimulation as that observed with quinpirole $[1 \mu \mathrm{M}]$. Data represent means \pm SEM from three independent experiments, each performed in triplicate. 


\subsection{Influence of GRK2/3 on $\beta$-Arrestin 2 Recruitment to the $D_{2 l o n g} R$ and the $D_{3} R$}

According to a generally accepted paradigm, G-protein coupled receptor kinases (GRKs) directly link the attenuation of G-protein signaling to arrestin recruitment and therefore play an important role in the desensitization and internalization processes of GPCRs [21]. However, a large body of this knowledge was gained from studies with the $\beta_{2}$-adrenergic receptor [21] and it has been shown that there are significant differences among GPCRs. In the case of the $\mathrm{D}_{2}$-like receptors, it was shown that especially GRK2 and 3 play an important role in these processes [67]. The exact mechanism is not fully understood yet. Therefore we decided to investigate the influence of these kinases in the developed method. Firstly, effects of the selective GRK2/3 inhibitor compound 101 (cpd101) [68] were investigated. The cells co-expressing the ELucN- $\beta$ arr2 and the $\mathrm{D}_{2 \text { long }} \mathrm{R}$-ELucC or $\mathrm{D}_{3} \mathrm{R}$-ELucC were pre-incubated with the inhibitor at increasing concentrations and concentration-response curves of quinpirole were generated, as displayed in Figure 6. Surprisingly, the inhibition of GRK2/3 in the cells expressing the $\mathrm{D}_{2 \text { long }} \mathrm{R}$ led to an increase in the luminescence signal to almost $400 \%(p<0.05)$ (Figure 6A) and the potency was decreased by almost one log unit $(p<0.05)$. Regarding the $\mathrm{D}_{3} \mathrm{R}$, the use of cpd101 had no significant effect on the efficacy $(p=0.21)$ or potency $(p=0.19)$ of quinpirole (Figure 6B). Since, for the $D_{1} R$, phosphorylation by GRK2 precedes the association of the $D_{1} R$ with $\beta$-arrestin2 [69], we constructed an analogous $\beta$-arrestin2 recruitment assay for the $D_{1} R$ (cf. Methods) as a control. The $\mathrm{D}_{1} \mathrm{R}$-ELucC construct was validated by radioligand saturation binding and $\beta$-arrestin 2 recruitment experiments and the results are presented in the Supplementary Materials (Figures S2 and S3, Tables S1 and S2). All data were in agreement with data from wild-type receptors. Subsequently, the influence of the inhibition of GRK2/3 by using cpd101 was investigated. As expected, inhibition of the kinases led to a concentration-dependent decrease in maximal response induced by the $\mathrm{D}_{1} \mathrm{R}$ standard agonist SKF81297 (cf. Figure 6 C) by about $47 \%(p<0.05)$ and the potency was only affected to a minor extent $(p=0.87)$. To further unravel the effects of the GRKs, the impact of exogenous overexpression of GRK2 and/or GRK3 on $\beta$-arrestin2 recruitment to the $D_{2 l o n g} R$ and $D_{3} R$ was investigated. The HEK293T cells expressing ELucN- $\beta$ arr2 and $\mathrm{D}_{2 \text { long }} \mathrm{R}$-ELucC or $\mathrm{D}_{3} \mathrm{R}$-ELucC were transiently transfected with a plasmid encoding GRK2 or GRK3. Their response to stimulation with quinpirole was compared to the response of cells that were mock transfected with the empty vector. As illustrated in Figure 7A, GRK2 overexpression in the $\mathrm{D}_{2 \text { long }} \mathrm{R}$-ELucC expressing cells led to a slight increase in luminescence signal, although this was not statistically significant $(p=0.17)$. Interestingly, the overexpression of GRK3 led to a marked decrease in luminescence signal $(p<0.05)$ to about $59 \%$ of the maximum signal exhibited by the mock transfected cells. This led to the assumption that the increase of the luminescence signal in the experiments with cpd101 (Figure 6) is mainly caused by the inhibition of GRK3. The $\beta$-arrestin2 recruitment to the $\mathrm{D}_{3} \mathrm{R}$ (Figure 7B) was not affected $(p=0.21)$ by exogenous GRK2 overexpression, suggesting that endogenous levels of the GRKs are sufficient to ensure $\beta$-arrestin2 recruitment or that GRKs are only marginally involved in this process. Additionally, the potency of quinpirole at either receptor was not altered $(p>0.05)$.
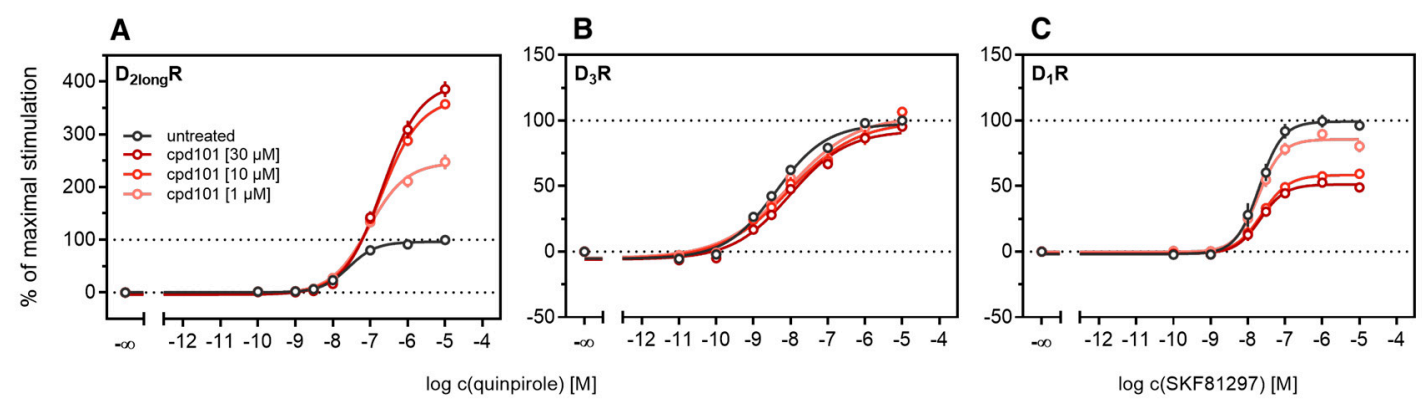

Figure 6. Influence of the GRK2/3 inhibitor cpd101 on $\beta$-arrestin2 recruitment. HEK293T cells stably expressing ELucN-ßarr2 and the indicated $D_{x} R$-ELucC were incubated with cpd101 at different concentrations for $40 \mathrm{~min}$ prior to agonist addition (A-C). Data represent means $\pm \mathrm{SEM}$ from three independent experiments, each performed in triplicate. 


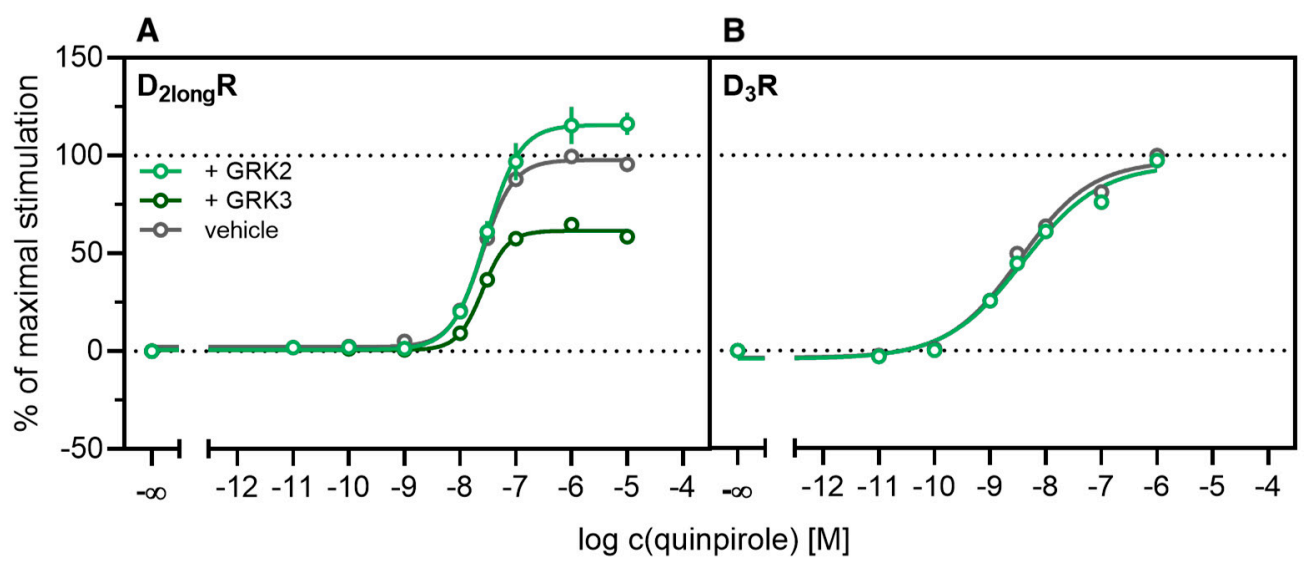

Figure 7. Influence of exogenous GRK2 or GRK3 overexpression on $\beta$-arrestin2 recruitment. HEK293T cells stably co-expressing ELucN- $\beta$ arr2 and the $D_{x}$ R-ELucC were transiently transfected with GRK2/GRK3 or empty vector $(\mathbf{A}, \mathbf{B})$. Data represent means \pm SEM from three independent experiments, each performed in triplicate or quadruplicate.

Our results regarding the $D_{1} R$ are in line with previous findings, confirming that phosphorylation of the receptor by GRK2 initiates or facilitates the interaction of the $D_{1} R$ with $\beta$-arrestin2 [69]. In contrast to the $D_{1} R$, the involvement of GRK2 in $\beta$-arrestin2 recruitment to the $D_{2 l o n g} R$ is controversially discussed in the literature. It has been reported that inhibition of the kinase activity of GRK2 leads to reduction of arrestin recruitment [70]. However, it has also been reported that GRK-mediated phosphorylation of the $D_{2 l o n g} R$ is not necessary for $\beta$-arrestin association [71] and that GRK2 is constitutively associated with the receptor, whereby $D_{2 l o n g} R$ signaling is constitutively suppressed [67]. To the best of our knowledge, the contribution of the GRK3 to phosphorylation or trafficking processes of the $D_{2 l o n g} R$ has not been subject to extensive studies so far. Our findings suggest that the GRK3 somehow hampers the recruitment of $\beta$-arrestin 2 to the receptor. The inhibitor cpd101 binds to the active site of GRK2/3 and thus blocks the binding of ATP to the enzyme [68]. Since application of the inhibitor led to a marked increase in luminescence signal (Figure 6A), this led us to the assumption that the kinase activity of the enzyme hampers $\beta$-arrestin recruitment to the $D_{2 l o n g} R$. With respect to the $D_{3} R$, the findings are consistent with earlier publications, in that $\mathrm{D}_{3}$ Rs only undergo subtle phosphorylation by GRKs and that they are regulated differently than $\mathrm{D}_{2} \mathrm{Rs}$ [72].

The kinetic profiles of $\beta$-arrestin2 recruitment to the $D_{2 l o n g} R$ and the $D_{1} R$ under the influence of cpd101 are shown in Figure 8. In both cases, the time courses of the GPCR/ $\beta$-arrestin interaction with and without cpd101 were similar; only the efficacy was influenced in opposite directions. It is noteworthy that the kinetic course of $\beta$-arrestin 2 recruitment to both receptors differs markedly. For the $D_{1} R$, it has been described that $\beta$-arrestin 2 is recruited rapidly, whereas the complex of receptor and arrestin is relatively unstable and already dissociates at the plasma membrane [28]. These findings are reflected by the course of our kinetic measurement, where we observed a steep increase in luminescence signal followed by a rapid decline after reaching a maximum (Figure $8 \mathrm{~B}$ ). This contrasts with the kinetic behavior at the $\mathrm{D}_{2 \text { long }} \mathrm{R}$, where the luminescent signal appears to stabilize (Figure $8 \mathrm{~A}$ ), suggesting that there is a more stable interaction between the $D_{2 l o n g} R$ and $\beta$-arrestin2. 
A

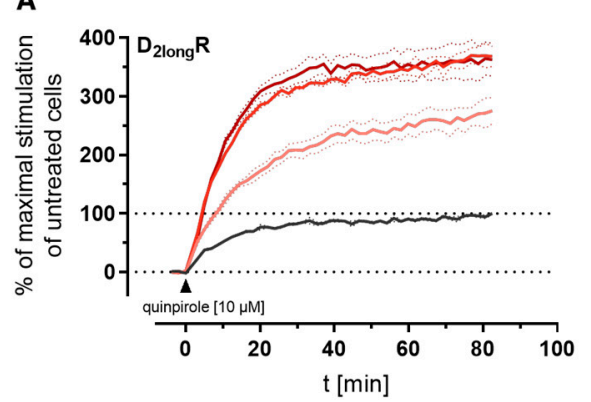

B

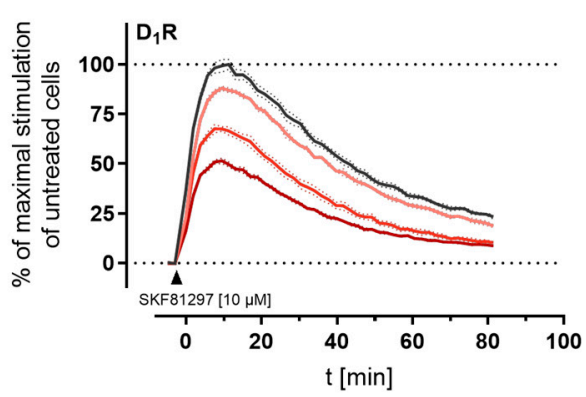

Figure 8. Impact of the specific GRK2/3 inhibitor cpd101 on the kinetics of $\beta$-arrestin2 recruitment to the $D_{2 l o n g} R(A)$ and the $D_{1} R(B)$. Data represent means \pm SEM from three independent experiments, each performed in triplicate.

\subsection{Influence of PKC on $\beta$-Arrestin 2 Recruitment to the $D_{3} R$}

Different studies on the internalization of $\mathrm{D}_{3}$ receptors have confirmed that the GRK/arrestindependent pathway plays a subordinate role for these receptors, which is consistent with our results described above (cf. Figures 6 and 7). It has been reported that $D_{3} R s$ are mainly internalized after phosphorylation by PKC [38,73]. PKC is known to play a part in heterologous desensitization of GPCRs [38], so we tested whether it contributes to agonist-induced $\beta$-arrestin2 recruitment to the $\mathrm{D}_{3} \mathrm{R}$. We used Gö6983, an inhibitor of different PKC isoenzymes, to abrogate the PKC-dependent phosphorylation of the $\mathrm{D}_{3} \mathrm{R}$ [73]. The cells were treated with increasing concentrations of the inhibitor before the concentration-response curves of quinpirole were recorded. As shown in Figure 9, inhibition of the PKC led to a significant decrease $(p<0.05)$ of the maximum response elicited by quinpirole. Moreover, the potency of quinpirole was decreased when cells were treated with the inhibitor before the measurement, but not with statistical significance $(p=0.19)$. Altogether, these results suggest that PKC-dependent phosphorylation facilitates $\beta$-arrestin2 recruitment to the $D_{3} R$.

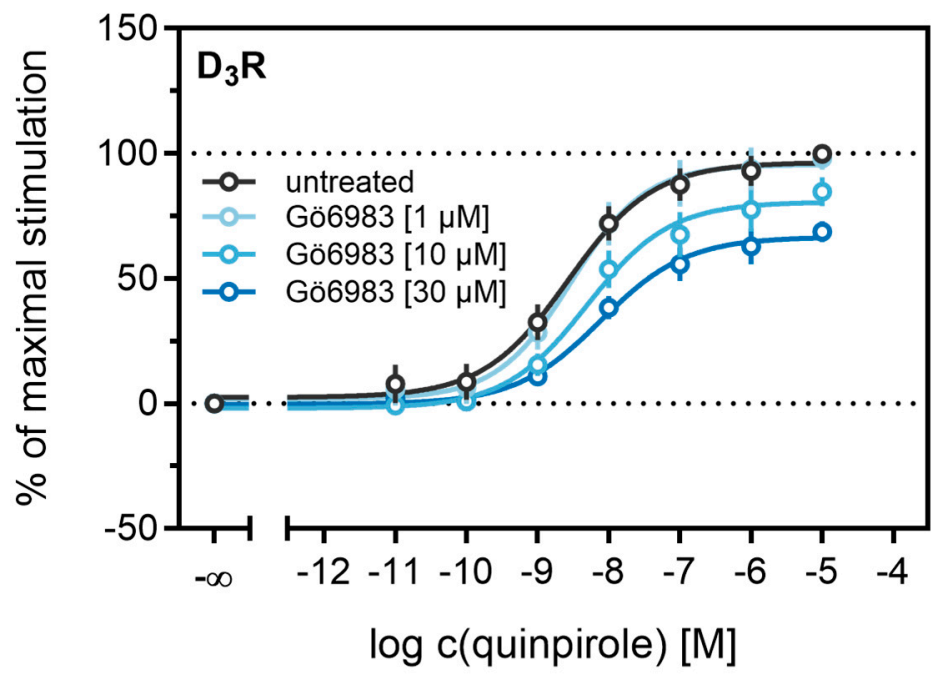

Figure 9. Influence of the PKC inhibitor Gö6983 on $\beta$-arrestin2 recruitment. HEK293T cells stably expressing ELucN-ßarr2 and $D_{3}$ R-ELucC were incubated with Gö6983 at different concentrations 40 min prior to addition of agonist. Data represent means \pm SEM from three independent experiments, each performed in triplicate. 


\section{Materials and Methods}

\subsection{Materials}

Dulbecco's modified Eagle's medium (DMEM) was from Sigma (Taufkirchen, Germany). Leibovitz' L-15 medium (L-15) was from Fisher Scientific (Nidderau, Germany). Fetal calf serum (FCS), trypsin/EDTA and geneticin (G418) were from Merck Biochrom (Darmstadt, Germany). Zeocin was purchased from Invivogen Europe (Toulouse, France). The cDNAs of the $h \mathrm{D}_{2 \text { long }} \mathrm{R}$ and $h \mathrm{D}_{3} \mathrm{R}$ were kindly provided by Dr. Harald Hübner (Department of Chemistry and Pharmacy, Friedrich-Alexander-University, Erlangen). cDNAs of the $D_{1} R$ and the $D_{4.4} R$ were purchased from the cDNA Resource Center (Rolla, MO, USA). pcDNA3.1/myc-HIS (B) containing the sequence of the $\beta$-arrestin2 fusion construct with the N-terminal fragment of the click beetle luciferase was kindly provided by Prof. Dr. Takeaki Ozawa (Department of Chemistry, School of Science, University of Tokyo). The pIRESneo3 vector was a gift from Prof. G. Meister (Institute of Biochemistry, Genetics, and Microbiology, University of Regensburg, Germany). pcDNA-GRK3 was a gift from Robert Lefkowitz [74] (Addgene plasmid \# 32,689; http://n2t.net/addgene:32689; RRID:Addgene_32689). If possible, ligands were dissolved in $\mathrm{H}_{2} \mathrm{O}$ (millipore); otherwise in DMSO (Merck, Darmstadt, Germany). (+)-butaclamol, dopamine, Gö6983, pramipexole, quinpirole and SKF81297 were from Sigma (Taufkirchen, Germany), aripiprazole and haloperidol were from TCI Deutschland GmbH (Eschborn, Germany), $R$-(-)-apomorphine, nemonapride, $S$-(-)-sulpiride, domperidone and Takeda compound 101 (cpd101) were from Tocris Bioscience (Bristol, United Kingdom). Pierce D-luciferin was purchased as a potassium salt from Fisher Scientific GmbH (Schwerte, Germany).

\subsection{Cell Culture}

HEK293T cells obtained as a kind gift from Prof. Dr. Wulf Schneider (Institute for Medical Microbiology and Hygiene, Regensburg, Germany) were cultured in DMEM supplemented with 10\% fetal calf serum at $37^{\circ} \mathrm{C}$ in a water-saturated atmosphere containing $5 \% \mathrm{CO}_{2}$. Cells were routinely tested for mycoplasma contamination using the Venor GeM Mycoplasma Detection Kit (Minerva Biolabs, Germany) and were negative.

\subsection{Generation of Plasmids for Cells Used in the $\beta$-Arrestin2 Recruitment Assay}

The fusion construct of the respective dopamine receptor and the C-terminal fragment of the luciferase was generated by using the previously described pcDNA4/V5-HIS (B) vector containing the $h \mathrm{H}_{1} \mathrm{R}$-ELucC construct [75]. The sequence of the $h \mathrm{H}_{1} \mathrm{R}$ was replaced by the cDNA of the $h \mathrm{D}_{1} \mathrm{R}$, $h \mathrm{D}_{2 \text { long }} \mathrm{R}, h \mathrm{D}_{3} \mathrm{R}$ or the $h \mathrm{D}_{4.4} \mathrm{R}$. The cDNAs were amplified by standard polymerase chain reaction (PCR) using gene specific primers and the Q5 high fidelity DNA polymerase (New England Biolabs, Ipswich, MA, USA). The sequences encoding the receptor-ELucC fusion constructs were cloned into the vector by standard restriction and ligation techniques. The quality of the vectors was controlled by sequencing (Eurofins Genomics GmbH, Ebersberg, Germany).

\subsection{Generation of Plasmids for Cells Used for Homogenate Preparation}

The $h \mathrm{D}_{1} \mathrm{R}, h \mathrm{D}_{2 \text { long }} \mathrm{R}, h \mathrm{D}_{3} \mathrm{R}$ and $h \mathrm{D}_{4.4} \mathrm{R}$ were cloned into a pIRESneo3 vector via Gibson Assembly. The pIRESneo3-SP-FLAG- $h \mathrm{H}_{4} \mathrm{R}$ vector, described elsewhere [76], was linearized using standard PCR techniques. Overlaps, complementary to the vector backbone were attached to the dopamine receptors using PCR. Subsequently, receptors were cloned into pIRESneo3 according to the NEBuilder HiFi DNA Assembly Reaction Protocol, resulting in receptors that are N-terminally fused to the membrane signal peptide (SP) of the murine $5-\mathrm{HT}_{3 \mathrm{~A}}$ receptor and tagged with a codon-optimized FLAG tag, subsequently referred to as wild-type receptors. The quality of the vectors was controlled by sequencing. 


\subsection{Generation of Stable Transfectants}

HEK293T cells stably expressing the $\beta$-arrestin2 fusion construct were generated as previously described [45]. The cells were seeded into a 6-well plate $24 \mathrm{~h}$ prior to transfection. For the transfection with the pcDNA3.1/myc-HIS (B) vector encoding the ELucN-ßarr2 fusion construct, Fugene HD transfection reagent (Promega, Mannheim, Germany) was used. Cells were incubated with $2 \mu \mathrm{g}$ of plasmid DNA at $37^{\circ} \mathrm{C}$ for $48 \mathrm{~h}$. Before starting with the antibiotic selection, cells were detached with trypsin/EDTA and transferred to a $75-\mathrm{cm}^{2}$ culture flask. G418 at a final concentration of $1000 \mu \mathrm{g} / \mathrm{mL}$ was added to the culture medium until stable growth was observed (for up to 3 weeks). Subsequently, cells were transfected with $2 \mu \mathrm{g}$ of the pcDNA4/V5-HIS (B) vector encoding the cDNAs for the dopamine receptor fusion proteins $\left(\mathrm{D}_{1} \mathrm{R}\right.$-ELucC, $\mathrm{D}_{2 \text { long }} \mathrm{R}$-ELucC, $\mathrm{D}_{3} \mathrm{R}$-ELucC, $\mathrm{D}_{4.4} \mathrm{R}$-ELucC) as described above with the exception that X-tremeGENE HP (Roche, Basel, Switzerland) was used as transfection reagent. Selection was performed with $400 \mu \mathrm{g} / \mathrm{mL}$ zeocin. Subsequently, a clonal selection was performed with every cell line for high expression of the modified receptor and $\beta$-arrestin 2 fusion construct. Therefore, stably transfected cells (see above) were seeded on a $15 \mathrm{~cm}$ dish at a density of 1000-2000 cells/dish. After 2 weeks, single clones were picked and screened for the highest $\mathrm{S} / \mathrm{B}$ ratios as described in Figure 2 by using $1 \mu \mathrm{M}$ quinpirole. HEK293T cells stably expressing the wild-type receptors were generated in an analogous manner. Briefly, $2 \mu$ g of the pIRESneo3 SP-FLAG- $D_{1} R / D_{2 l o n g} R / D_{3} R / D_{4.4} R$ vector were used and selection was achieved in the presence of $600 \mu \mathrm{g} / \mathrm{mL}$ of G418.

\subsection{Preparation of Cell Homogenates}

Homogenates were prepared as previously described [77] with minor modifications. HEK293T cells stably expressing the $D_{1} R, D_{2 l o n g} R$, the $D_{3} R$ or the $D_{4.4} R$ were grown in $15 \mathrm{~cm}$ dishes to $80-90 \%$ confluency. Cells were rinsed with ice-cold PBS (137 mM NaCl, $2.7 \mathrm{mM} \mathrm{KCl}, 10 \mathrm{mM} \mathrm{Na} 2 \mathrm{HPO}_{4}$, $\left.1.8 \mathrm{mM} \mathrm{KH}_{2} \mathrm{PO}_{4}, \mathrm{pH} 7.4\right)$ and detached from the dishes using a cell scraper in the presence of harvest buffer (10 mM Tris. $\mathrm{HCl}, 0.5 \mathrm{mM}$ EDTA, $5.5 \mathrm{mM} \mathrm{KCl}, 140 \mathrm{mM} \mathrm{NaCl}$; pH 7.4) supplemented with protease inhibitors (SigmaFAST, Cocktail Tablets, EDTA-free, Sigma-Aldrich, Deisenhofen, Germany). After centrifugation $(500 \times g, 5 \mathrm{~min})$, the $\mathrm{D}_{21 \text { long }} \mathrm{R}$ expressing cells were resuspended in homogenate buffer (50 mM Tris.HCl, $5 \mathrm{mM}$ EDTA, $1.5 \mathrm{mM} \mathrm{CaCl}_{2}, 5 \mathrm{mM} \mathrm{MgCl} 2,5 \mathrm{mM} \mathrm{KCl}, 120 \mathrm{mM} \mathrm{NaCl}$; $\mathrm{pH}$ 7.4), whereas the $\mathrm{D}_{3} \mathrm{R}$ or $\mathrm{D}_{4.4} \mathrm{R}$ expressing cells were resuspended in Tris- $\mathrm{MgSO}_{4}$ buffer $(10 \mathrm{mM}$ Tris. $\mathrm{HCl}, 5 \mathrm{mM} \mathrm{MgSO}$; $\mathrm{pH} 7.4$ ) and stored at $-80^{\circ} \mathrm{C}$. After thawing, the cells were resuspended in homogenate buffer or Tris- $\mathrm{MgSO}_{4}$ buffer, and homogenized using an Ultraturrax (on ice, 5 times for $5 \mathrm{~s})$. The homogenate was centrifuged $\left(6^{\circ} \mathrm{C}, 50,000 \times g, 15 \mathrm{~min}\right)$, the pellet was resuspended in binding buffer (50 mM Tris.HCl, 1 mM EDTA, 5 mM MgCl $2,100 \mu \mathrm{g} / \mathrm{mL}$ bacitracin; $\mathrm{pH}$ 7.4) and homogenized using a syringe and needle (i.d. $=0.4 \mathrm{~mm}$ ). The homogenate was stored in small aliquots at $-80^{\circ} \mathrm{C}$.

\subsection{Radioligand Binding Experiments with Whole Cells}

For radioligand saturation binding with whole cells, expressing the developed $D_{1} R-, D_{2 l o n g} R-$, $\mathrm{D}_{3} \mathrm{R}$ - or $\mathrm{D}_{4.4} \mathrm{R}$-ELucC fusion constructs, cells were cultured in a $75 \mathrm{~cm}^{2}$ flask to a confluency of approx. $80 \%$, detached with a cell scraper and resuspended in L-15 containing 5\% FCS. After centrifugation $(600 \times g, 5 \mathrm{~min})$, the cells were resuspended in L-15 medium containing $100 \mu \mathrm{g} / \mathrm{mL}$ bacitracin at a density of $0.15 \times 10^{6}$ cells $/ \mathrm{mL}$. The assay was carried out in a final volume of $200 \mu \mathrm{L} /$ well in 96 -well polypropylene plates. The radioligand $\left[{ }^{3} \mathrm{H}\right] \mathrm{SCH} 23390\left(\mathrm{D}_{1} \mathrm{R}\right.$; specific activity: $81 \mathrm{Ci} / \mathrm{mmol}$, Novandi Chemistry $A B$, Södertälje, Sweden) was for the $D_{1} R$ in a concentration range from $0.04 \mathrm{nM}$ to $4 \mathrm{nM}$. For the $\mathrm{D}_{2,3,4.4} \mathrm{R},\left[{ }^{3} \mathrm{H}\right] \mathrm{N}$-methylspiperone $\left(\mathrm{D}_{2,3,4.4} \mathrm{R}\right.$; specific activity: $77 \mathrm{Ci} / \mathrm{mmol}$, Novandi Chemistry $\mathrm{AB}$, Södertälje, Sweden) was used in a concentration range from $0.025 \mathrm{nM}$ to $1.5 \mathrm{nM}$ for the $\mathrm{D}_{2 \text { long }} \mathrm{R}$ and the $D_{3} R$ or $3.0 \mathrm{nM}$ for the $D_{4.4} R$. After incubation for $60 \mathrm{~min}\left(D_{2 l o n g, 3,4.4} R\right)$ or $120 \mathrm{~min}\left(D_{1} R\right)$ at room temperature, bound radioligand was separated from free radioligand by filtration through PEI-coated GF/C filters using a 96-well Brandel harvester (Brandel Inc., Unterföhring, Germany). Filters were transferred to (flexible) 1450-401 96-well sample plates (PerkinElmer, Rodgau, Germany) and after 
incubation with scintillation cocktail (Rotiszint eco plus, Carl Roth, Karlsruhe, Germany) for 5 h, radioactivity was measured using a MicroBeta2 plate counter (PerkinElmer, Waltham, MA, USA). Total and nonspecific data were fitted by the model "one site-total and nonspecific binding" using a hyperbolic curve fit for total binding and linear regression for nonspecific binding. Specific binding was fitted to the model "one site-specific binding". $K_{d}$ values were transformed into $p K_{d}$ and means and SEMs were calculated from the respective $\mathrm{p} K_{\mathrm{d}}$ values.

Competition binding experiments with whole cells expressing the fusion proteins were carried out analogous to saturation binding experiments with whole cells as described above. $\left[{ }^{3} \mathrm{H}\right] \mathrm{N}$-methylspiperone was applied at a final concentration of $0.06 \mathrm{nM}$ for the $\mathrm{D}_{2 \text { long }} \mathrm{R}$ and the $\mathrm{D}_{3} \mathrm{R}$ or $0.5 \mathrm{nM}$ for the $\mathrm{D}_{4.4} \mathrm{R}$. Nonspecific binding was determined in the presence of $2 \mu \mathrm{M}(+)$-butaclamol $\left(D_{2 l o n g} R, D_{3} R\right)$ or nemonapride $\left(D_{4.4} R\right)$. Competition binding curves were fitted using a four parameter fit ("log(agonist) vs. response-variable slope") or a two site fit ("two sites-fit $\log \mathrm{IC}_{50}$ "). Significance of biphasic fitting was tested using the "extra sum-of-squares F Test" provided by GraphPad. $p$ values < 0.05 were considered to indicate statistical significance. All calculations were conducted using Prism 8 (Graph Pad, La Jolla, CA, USA).

\subsection{Radioligand Binding Experiments with Homogenates}

Radioligand binding experiments with homogenates were performed as described for whole cells (see above) with minor modifications. For saturation binding experiments homogenates containing the respective dopamine receptor were resuspended in binding buffer $(50 \mathrm{mM}$ Tris $\cdot \mathrm{HCl}, 1 \mathrm{mM}$ EDTA, $5 \mathrm{mM} \mathrm{MgCl}_{2}$ and $100 \mu \mathrm{g} / \mathrm{mL}$ bacitracin, $\left.\mathrm{pH}=7.4\right)$ to a final concentration of $0.3 \mu \mathrm{g}\left(\mathrm{D}_{1} \mathrm{R}\right)$, $0.3 \mu \mathrm{g}\left(\mathrm{D}_{\text {2long }} \mathrm{R}\right), 0.7 \mu \mathrm{g}\left(\mathrm{D}_{3} \mathrm{R}\right)$ or $0.5-1.0 \mu \mathrm{g}\left(\mathrm{D}_{4.4} \mathrm{R}\right)$ protein/well. Incubation time was $60 \mathrm{~min}$ for the $D_{2 l o n g} R, D_{3} R$ and $D_{4.4} R$ or 120 min for the $D_{1} R$. Unspecific binding was determined in the presence of (+)-butaclamol (2000-fold excess, $\mathrm{D}_{1} \mathrm{R}, \mathrm{D}_{2 \text { long }} \mathrm{R}, \mathrm{D}_{3} \mathrm{R}$ ) or nemonapride (2000-fold, $\mathrm{D}_{4.4} \mathrm{R}$ ). $\left[{ }^{3} \mathrm{H}\right] \mathrm{SCH} 23390$ $\left(\mathrm{D}_{1} \mathrm{R}\right.$; specific activity: $81 \mathrm{Ci} / \mathrm{mmol}$, Novandi Chemistry $\mathrm{AB}$, Södertälje, Sweden) was used in a concentration range from $0.04 \mathrm{nM}$ to $7 \mathrm{nM}$ for the $D_{1} R$. $\left[{ }^{3} \mathrm{H}\right] N$-methylspiperone $\left(D_{2,3,4.4} R\right.$; specific activity: $77 \mathrm{Ci} / \mathrm{mmol}$, Novandi Chemistry $\mathrm{AB}$, Södertälje, Sweden) was used in a concentration range from $0.025 \mathrm{nM}$ to $1.5 \mathrm{nM}$ for the $\mathrm{D}_{2 \text { long }} \mathrm{R}$ and the $\mathrm{D}_{3} \mathrm{R}$ or $3.0 \mathrm{nM}$ for the $\mathrm{D}_{4.4} \mathrm{R}$.

For competition binding experiments, $\left[{ }^{3} \mathrm{H}\right] \mathrm{N}$-methylspiperone was applied at a final concentration of $0.06 \mathrm{nM}$ for the $\mathrm{D}_{2 \text { long }} \mathrm{R}$ and the $\mathrm{D}_{3} \mathrm{R}$ or $0.1 \mathrm{nM}$ for the $\mathrm{D}_{4.4} \mathrm{R}$. Incubation time was $60 \mathrm{~min}$.

\subsection{Quantification of $\beta$-Arrestin2 Recruitment in Live Cells}

HEK293T ELucN-ßarr2 cells stably expressing the dopamine receptor-ELucC fusion protein were detached from a $75-\mathrm{cm}^{2}$ flask by trypsinization and centrifuged $(700 \times g, 5 \mathrm{~min})$. The pellet was resuspended in L-15 medium supplemented with $5 \%$ FCS, HEPES $(10 \mathrm{mM})$, and the cell density was adjusted to $1.25 \times 10^{6}$ cells $/ \mathrm{mL}$. Then, $80 \mu \mathrm{L} /$ well of this suspension were seeded into a white microtiter 96-well cellGrade plate (Brand \& Co. KG, Wertheim, Germany) and incubated overnight at $37^{\circ} \mathrm{C}$ in a humidified atmosphere. The next day, $10 \mu \mathrm{L}$ of a $10 \mathrm{mM}$ solution of D-luciferin in L-15 medium was added to each well and the plate was transferred to a pre-warmed $\left(37^{\circ} \mathrm{C}\right)$ INFINITE 200 Pro microplate reader (Tecan, Grödig, Austria). A baseline was measured for $20 \mathrm{~min}$ by recording the luminescence of the entire plate for $100 \mathrm{~ms}$ per well in 11 cycles. Serial dilutions of the respective agonists or antagonists were prepared in L-15 medium containing HEPES (10 mM) (assay buffer) and warmed to $37^{\circ} \mathrm{C}$ prior to addition to the cells. Subsequently, luminescence was recorded for 45 repeats resulting in an overall time period of $1 \mathrm{~h}$. Negative control (assay buffer) and positive control (quinpirole $\left(\mathrm{D}_{2 l o n g} \mathrm{R}\right)$, full agonist) were included for normalization of the data from the $D_{2 l o n g} R$. For measurements performed in antagonist mode, $10 \mu \mathrm{L}$ of assay buffer were removed from each well before cells were pre-incubated with the antagonist dilutions $(10 \mu \mathrm{L})$ for $20 \mathrm{~min}$. Antagonists were added simultaneously with the substrate just before starting the baseline measurement. Then, quinpirole $\left(D_{2 l o n g} R\right)$ or SKF81297 $\left(D_{1} R\right)$ was added at a concentration eliciting $80 \%$ of the maximal response and the final read was started. To correct for slight differences in cell counts or amount of substrate added to each well, the mean of 
the baseline values just before addition of agonists was subtracted from all subsequently recorded values. Additionally, to account for a change of luminescence that might occur over the time-course of the measurement in the absence of agonist, the recorded values of the solvent control were subtracted from all data. For generating concentration-response curves, the AUC after 50 min was used. Data were fitted to the model "log(agonist) vs. response-variable slope (four parameters)". The $\mathrm{p} K_{\mathrm{b}}$-values were calculated from $\mathrm{IC}_{50}$ values according to the Cheng-Prusoff equation [78]. All calculations were conducted using Prism 8 (Graph Pad, La Jolla, CA, USA).

\subsection{Quantification of $\beta$-Arrestin2 Recruitment by Endpoint Measurement}

HEK293T ELucN-ßarr2 cells stably expressing the dopamine receptor-ELucC fusion protein were prepared $24 \mathrm{~h}$ before as described in the preceding section. In agonist mode, $10 \mu \mathrm{L}$ of assay buffer were added to each well before addition of $10 \mu \mathrm{L}$ of agonist in different concentrations, resulting in an assay volume of $100 \mu \mathrm{L}$. In antagonist mode, cells were incubated with $10 \mu \mathrm{L}$ of antagonist in different concentrations for $20 \mathrm{~min}$, before quinpirole $(10 \mu \mathrm{L})$ was added at a concentration eliciting $80 \%$ of the maximum response. After incubating the cells with the compounds for $90 \mathrm{~min}$ at room temperature, $50 \mu \mathrm{L}$ of assay medium from each well were replaced by $50 \mu \mathrm{L}$ of Bright-Glo luciferase assay reagent. Plates were vigorously shaken for $2 \mathrm{~min}$ and bioluminescence was recorded for $1 \mathrm{~ms}$ per well using an INFINITE 200 Pro microplate reader (Tecan, Grödig, Austria). Data were fitted to the model "log(agonist) vs. response-variable slope (four parameters)". The $\mathrm{p} K_{\mathrm{b}}$-values were calculated from $\mathrm{IC}_{50}$ values according to the Cheng-Prusoff equation [78]. All calculations were conducted using Prism 8 (Graph Pad, La Jolla, CA, USA).

\subsection{Statistical Analysis}

Statistic differences were analyzed using a t-Test or a one-way ANOVA. All reported $p$ values are two-sided, and $p$ values lower than 0.05 were considered to indicate statistical significance. All calculations were performed using the SPSS 26 software (IBM, Armonk, NY, USA).

\subsection{Data Availability}

The datasets generated during the current study are available upon request.

\section{Summary and Conclusions}

In this study, we developed a split luciferase complementation $\beta$-arrestin2 recruitment assay for the $D_{2 l o n g}$ and the $D_{3}$ receptor, which, in case of the $D_{2 l o n g} R$, is also applicable in live cells. The hypothesis that the $\mathrm{D}_{4} \mathrm{R}$ does not recruit $\beta$-arrestin2 was confirmed [35], as no recruitment was measured at the $\mathrm{D}_{4.4} \mathrm{R}$. Our assay represents a homogeneous test principle with a cell-permeable substrate, which allows temporal (kinetic) measurements. Combined with the proximal readout and the short incubation time, it represents a significant improvement over the commercially available assays described above. For the $\mathrm{D}_{2 \text { long }}$ and $\mathrm{D}_{3}$ receptors, we demonstrated that the assay is suitable for the determination of ligand potencies and efficacies. Furthermore, the test system is able to discriminate between full and partial agonists and to identify inverse agonism at the $D_{3} R$, which makes it a versatile tool for the characterization of dopamine receptor ligands. Although $\beta$-arrestin2 recruitment at the $D_{3} R$ has played a rather minor role in the literature so far [33], this determination can still be an important parameter for the complete characterization and development of future biased ligands in the field of dopamine receptors. The influence of GRK2/3 and PKC at the $D_{2 l o n g} R, D_{3} R$, and $D_{1} R$ was investigated using different kinase inhibitors, which shows that the assay can also contribute to the deciphering of signaling mechanisms. In summary, this split luciferase complementation assay is a powerful tool for the determination of $\beta$-arrestin2 recruitment in dopamine $D_{2}$-like receptors. Thus it represents an important methodological extension for the identification of biased agonists, e.g., in multiparametric analyses, and the characterization of $\mathrm{D}_{2}$-like receptor ligands. 
Supplementary Materials: The following are available online at http://www.mdpi.com/1422-0067/21/17/6103/s1, Figure S1: Radioligand saturation binding curves with whole HEK293T ELucN- $\beta$ arr2 cells expressing the D2longR-ELucC (A), D3R-ELucC (B) or D4.4R-ELucC (C) fusion proteins and homogenates from cells expressing the wild-type D2longR (D), D3R (E) or D4.4R (F). Figure S2: Radioligand saturation binding curves with whole HEK293T ELucN- $\beta$ arr2 cells expressing the D1R-ELucC (A) fusion proteins and homogenates from cells expressing the wild-type D1R (B). Figure S3: Characterization of the standard agonist SKF81297 and standard antagonist $\mathrm{SCH} 23390$ in the $\beta$-arrestin2 recruitment assay at the D1R. Table S1: Dissociation constants ( $\mathrm{pKd}$ values) of $\left[{ }^{3} \mathrm{H}\right] \mathrm{SCH} 23390$ determined in radioligand saturation binding experiments at receptors fused to the C-terminal fragment of the Emerald luciferase using whole cells and at wild-type receptors using homogenates. Table S2: pEC50, Emax and pKb values of SKF81297 and SCH23390 analysed in the newly developed $\beta$-arrestin2 recruitment assay at the D1R.

Author Contributions: Conceptualization, L.F., S.P. and G.B.; methodology, L.F. and L.G.; formal analysis, L.F. and D.M.; investigation, L.F. and D.M.; resources, S.P. and G.B.; data curation, L.F.; writing-original draft preparation, L.F. and S.P.; writing-review and editing, L.F., S.P., D.M., G.B. and L.G.; visualization, L.F. and S.P.; supervision, S.P. and G.B.; project administration, L.F., S.P. and G.B. All authors have read and agreed to the published version of the manuscript.

Funding: The Ph.D. position of Lukas Grätz is funded by the Deutsche Forschungsgemeinschaft (DFG, Research Training Group GRK 1910).

Acknowledgments: The authors thank Armin Buschauer and Sigurd Elz for providing infrastructure and scientific expertise, Takeaki Ozawa for providing the plasmids for the arrestin recruitment assay and Johannes Felixberger for implementing the arrestin recruitment assay in our group.

Conflicts of Interest: The authors declare no conflict of interest.

\section{References}

1. Cools, A.R.; Van Rossum, J.M. Excitation-mediating and inhibition-mediating dopamine-receptors: A new concept towards a better understanding of electrophysiological, biochemical, pharmacological, functional and clinical data. Psychopharmacologia 1976, 45, 243-254. [CrossRef] [PubMed]

2. Dearry, A.; Gingrich, J.A.; Falardeau, P.; Fremeau, R.T.; Bates, M.D., Jr.; Caron, M.G. Molecular cloning and expression of the gene for a human D1 dopamine receptor. Nature 1990, 347, 72-76. [CrossRef] [PubMed]

3. Sokoloff, P.; Giros, B.; Martres, M.-P.; Bouthenet, M.-L.; Schwartz, J.-C. Molecular cloning and characterization of a novel dopamine receptor (D3) as a target for neuroleptics. Nature 1990, 347, 146-151. [CrossRef] [PubMed]

4. Van Tol, H.H.; Bunzow, J.R.; Guan, H.C.; Sunahara, R.K.; Seeman, P.; Niznik, H.B.; Civelli, O. Cloning of the gene for a human dopamine D4 receptor with high affinity for the antipsychotic clozapine. Nature 1991, 350, 610-614. [CrossRef]

5. Polymeropoulos, M.H.; Xiao, H.; Merril, C.R. The human D5 dopamine receptor (DRD5) maps on chromosome 4. Genomics 1991, 11,777-778. [CrossRef]

6. Andersen, P.H.; Gingrich, J.A.; Bates, M.D.; Dearry, A.; Falardeau, P.; Senogles, S.E.; Caron, M.G. Dopamine receptor subtypes: Beyond the D1/D2 classification. Trends Pharmacol. Sci. 1990, 11, 231-236. [CrossRef]

7. Neve, K.A.; Seamans, J.K.; Trantham-Davidson, H. Dopamine receptor signaling. J. Recept. Signal Transduct. 2004, 24, 165-205. [CrossRef]

8. Kebabian, J.W. Multiple classes of dopamine receptors in mammalian central nervous system: The involvement of dopamine-sensitive adenylyl cyclase. Life Sci. 1978, 23, 479-483. [CrossRef]

9. Spano, P.F.; Govoni, S.; Trabucchi, M. Studies on the pharmacological properties of dopamine receptors in various areas of the central nervous system. Adv. Biochem. Psychopharmacol. 1978, 19, 155-165.

10. Neves, S.R.; Ram, P.T.; Iyengar, R. G protein pathways. Science 2002, 296, 1636-1639. [CrossRef]

11. Davis, K.L.; Kahn, R.S.; Ko, G.; Davidson, M. Dopamine in schizophrenia: A review and reconceptualization. Am. J. Psychiatry 1991, 148, 1474-1486. [CrossRef] [PubMed]

12. Bernheimer, H.; Birkmayer, W.; Hornykiewicz, O.; Jellinger, K.; Seitelberger, F. Brain dopamine and the syndromes of Parkinson and Huntington Clinical, morphological and neurochemical correlations. J. Neurol. Sci. 1973, 20, 415-455. [CrossRef]

13. Hoglinger, G.U.; Rizk, P.; Muriel, M.P.; Duyckaerts, C.; Oertel, W.H.; Caille, I.; Hirsch, E.C. Dopamine depletion impairs precursor cell proliferation in Parkinson disease. Nat. Neurosci. 2004, 7, 726-735. [CrossRef] [PubMed] 
14. Di Chiara, G. Drug addiction as dopamine-dependent associative learning disorder. Eur. J. Pharmacol. 1999, 375, 13-30. [CrossRef]

15. Di Chiara, G.; Bassareo, V.; Fenu, S.; De Luca, M.A.; Spina, L.; Cadoni, C.; Acquas, E.; Carboni, E.; Valentini, V.; Lecca, D. Dopamine and drug addiction: The nucleus accumbens shell connection. Neuropharmacology 2004, 47, 227-241. [CrossRef]

16. Albrecht, F.E.; Drago, J.; Felder, R.A.; Printz, M.P.; Eisner, G.M.; Robillard, J.E.; Sibley, D.R.; Westphal, H.J.; Jose, P.A. Role of the D1A dopamine receptor in the pathogenesis of genetic hypertension. J. Clin. Investig. 1996, 97, 2283-2288. [CrossRef]

17. Berk, M.; Dodd, S.; Kauer-Santanna, M.; Malhi, G.S.; Bourin, M.; Kapczinski, F.; Norman, T. Dopamine dysregulation syndrome: Implications for a dopamine hypothesis of bipolar disorder. Acta Psychiatr. Scand. 2007, 116, 41-49. [CrossRef]

18. Cousins, D.A.; Butts, K.; Young, A.H. The role of dopamine in bipolar disorder. Bipolar Disord. 2009, 11, 787-806. [CrossRef]

19. Linke, R.; Eisensehr, I.; Wetter, T.C.; Gildehaus, F.J.; Popperl, G.; Trenkwalder, C.; Noachtar, S.; Tatsch, K. Presynaptic dopaminergic function in patients with restless legs syndrome: Are there common features with early Parkinson's disease? Mov. Disord. 2004, 19, 1158-1162. [CrossRef]

20. Stiasny-Kolster, K.; Kohnen, R.; Schollmayer, E.; Moller, J.C.; Oertel, W.H.; Rotigotine Sp 666 Study Group. Patch application of the dopamine agonist rotigotine to patients with moderate to advanced stages of restless legs syndrome: A double-blind, placebo-controlled pilot study. Mov. Disord. 2004, 19, 1432-1438. [CrossRef]

21. Lohse, M.J.; Benovic, J.L.; Codina, J.; Caron, M.G.; Lefkowitz, R.J. Beta-Arrestin: A protein that regulates beta-adrenergic receptor function. Science 1990, 248, 1547-1550. [CrossRef] [PubMed]

22. Ferguson, S.S.; Downey, W.E., III; Colapietro, A.M.; Barak, L.S.; Menard, L.; Caron, M.G. Role of beta-arrestin in mediating agonist-promoted G protein-coupled receptor internalization. Science 1996, 271, 363-366. [CrossRef] [PubMed]

23. DeWire, S.M.; Ahn, S.; Lefkowitz, R.J.; Shenoy, S.K. Beta-arrestins and cell signaling. Annu. Rev. Physiol. 2007, 69, 483-510. [CrossRef] [PubMed]

24. Inglese, J.; Freedman, N.J.; Koch, W.J.; Lefkowitz, R.J. Structure and mechanism of the G protein-coupled receptor kinases. J. Biol. Chem. 1993, 268, 23735-23738.

25. Pippig, S.; Andexinger, S.; Daniel, K.; Puzicha, M.; Caron, M.G.; Lefkowitz, R.J.; Lohse, M.J. Overexpression of beta-arrestin and beta-adrenergic receptor kinase augment desensitization of beta 2-adrenergic receptors. J. Biol. Chem. 1993, 268, 3201-3208.

26. Oakley, R.H.; Laporte, S.A.; Holt, J.A.; Barak, L.S.; Caron, M.G. Molecular determinants underlying the formation of stable intracellular $\mathrm{G}$ protein-coupled receptor-beta-arrestin complexes after receptor endocytosis. J. Biol. Chem. 2001, 276, 19452-19460. [CrossRef]

27. Hilger, D.; Masureel, M.; Kobilka, B.K. Structure and dynamics of GPCR signaling complexes. Nat. Struct. Mol. Biol. 2018, 25, 4-12. [CrossRef]

28. Oakley, R.H.; Laporte, S.A.; Holt, J.A.; Caron, M.G.; Barak, L.S. Differential affinities of visual arrestin, beta arrestin1, and beta arrestin2 for $\mathrm{G}$ protein-coupled receptors delineate two major classes of receptors. J. Biol. Chem. 2000, 275, 17201-17210. [CrossRef]

29. Gainetdinov, R.R.; Premont, R.T.; Bohn, L.M.; Lefkowitz, R.J.; Caron, M.G. Desensitization of G protein-coupled receptors and neuronal functions. Annu. Rev. Neurosci. 2004, 27, 107-144. [CrossRef]

30. Beaulieu, J.M.; Gainetdinov, R.R. The physiology, signaling, and pharmacology of dopamine receptors. Pharmacol. Rev. 2011, 63, 182-217. [CrossRef]

31. Ito, K.; Haga, T.; Lameh, J.; Sadee, W. Sequestration of dopamine D2 receptors depends on coexpression of G-protein-coupled receptor kinases 2 or 5. Eur. J. Biochem. 1999, 260, 112-119. [CrossRef] [PubMed]

32. Iwata, K.; Ito, K.; Fukuzaki, A.; Inaki, K.; Haga, T. Dynamin and rab5 regulate GRK2-dependent internalization of dopamine D2 receptors. Eur. J. Biochem. 1999, 263, 596-602. [CrossRef] [PubMed]

33. Kim, K.M.; Valenzano, K.J.; Robinson, S.R.; Yao, W.D.; Barak, L.S.; Caron, M.G. Differential regulation of the dopamine D2 and D3 receptors by G protein-coupled receptor kinases and beta-arrestins. J. Biol. Chem. 2001, 276, 37409-37414. [CrossRef] [PubMed]

34. Kim, K.M.; Caron, M.G. Complementary roles of the DRY motif and C-terminus tail of GPCRS for G protein coupling and beta-arrestin interaction. Biochem. Biophys. Res. Commun. 2008, 366, 42-47. [CrossRef] 
35. Spooren, A.; Rondou, P.; Debowska, K.; Lintermans, B.; Vermeulen, L.; Samyn, B.; Skieterska, K.; Debyser, G.; Devreese, B.; Vanhoenacker, P.; et al. Resistance of the dopamine D4 receptor to agonist-induced internalization and degradation. Cell. Signal. 2010, 22, 600-609. [CrossRef]

36. Deming, J.D.; Shin, J.A.; Lim, K.; Lee, E.J.; Van Craenenbroeck, K.; Craft, C.M. Dopamine receptor D4 internalization requires a beta-arrestin and a visual arrestin. Cell. Signal. 2015, 27, 2002-2013. [CrossRef]

37. Min, C.; Zheng, M.; Zhang, X.; Caron, M.G.; Kim, K.M. Novel roles for beta-arrestins in the regulation of pharmacological sequestration to predict agonist-induced desensitization of dopamine D3 receptors. Br. J. Pharmacol. 2013, 170, 1112-1129. [CrossRef]

38. Cho, E.Y.; Cho, D.I.; Park, J.H.; Kurose, H.; Caron, M.G.; Kim, K.M. Roles of protein kinase C and actin-binding protein 280 in the regulation of intracellular trafficking of dopamine D3 receptor. Mol. Endocrinol. 2007, 21, 2242-2254. [CrossRef]

39. Masri, B.; Salahpour, A.; Didriksen, M.; Ghisi, V.; Beaulieu, J.M.; Gainetdinov, R.R.; Caron, M.G. Antagonism of dopamine D2 receptor/beta-arrestin 2 interaction is a common property of clinically effective antipsychotics. Proc. Natl. Acad. Sci. USA 2008, 105, 13656-13661. [CrossRef]

40. Littmann, T.; Buschauer, A.; Bernhardt, G. Split luciferase-based assay for simultaneous analyses of the ligand concentration- and time-dependent recruitment of beta-arrestin2. Anal. Biochem. 2019, 573, 8-16. [CrossRef]

41. Song, Y.B.; Park, C.O.; Jeong, J.Y.; Huh, W.K. Monitoring G protein-coupled receptor activation using an adenovirus-based beta-arrestin bimolecular fluorescence complementation assay. Anal. Biochem. 2014, 449, 32-41. [CrossRef] [PubMed]

42. Laroche, G.; Giguere, P.M. Measurement of beta-Arrestin Recruitment at GPCRs Using the Tango Assay. Methods Mol. Biol. 2019, 1947, 257-267. [CrossRef] [PubMed]

43. Eishingdrelo, H.; Cai, J.; Weissensee, P.; Sharma, P.; Tocci, M.J.; Wright, P.S. A cell-based protein-protein interaction method using a permuted luciferase reporter. Curr. Chem. Genom. 2011, 5, 122-128. [CrossRef] [PubMed]

44. Viviani, V.R.; Arnoldi, F.G.; Neto, A.J.; Oehlmeyer, T.L.; Bechara, E.J.; Ohmiya, Y. The structural origin and biological function of $\mathrm{pH}$-sensitivity in firefly luciferases. Photochem. Photobiol. Sci. 2008, 7, 159-169. [CrossRef] [PubMed]

45. Misawa, N.; Kafi, A.K.; Hattori, M.; Miura, K.; Masuda, K.; Ozawa, T. Rapid and high-sensitivity cell-based assays of protein-protein interactions using split click beetle luciferase complementation: An approach to the study of G-protein-coupled receptors. Anal. Chem. 2010, 82, 2552-2560. [CrossRef] [PubMed]

46. Hattori, M.; Tanaka, M.; Takakura, H.; Aoki, K.; Miura, K.; Anzai, T.; Ozawa, T. Analysis of temporal patterns of GPCR-beta-arrestin interactions using split luciferase-fragment complementation. Mol. Biosyst. 2013, 9 , 957-964. [CrossRef] [PubMed]

47. Sibley, D.R.; De Lean, A.; Creese, I. Anterior pituitary dopamine receptors. Demonstration of interconvertible high and low affinity states of the D-2 dopamine receptor. J. Biol. Chem. 1982, 257, 6351-6361.

48. Sibley, D.R.; Mahan, L.C.; Creese, I. Dopamine receptor binding on intact cells. Absence of a high-affinity agonist-receptor binding state. Mol. Pharmacol. 1983, 23, 295-302.

49. Newman-Tancredi, A.; Cussac, D.; Audinot, V.; Nicolas, J.P.; De Ceuninck, F.; Boutin, J.A.; Millan, M.J. Differential actions of antiparkinson agents at multiple classes of monoaminergic receptor. II. Agonist and antagonist properties at subtypes of dopamine $\mathrm{D}(2)$-like receptor and alpha(1)/alpha(2)-adrenoceptor. J. Pharmacol. Exp. Ther. 2002, 303, 805-814. [CrossRef]

50. Allen, J.A.; Yost, J.M.; Setola, V.; Chen, X.; Sassano, M.F.; Chen, M.; Peterson, S.; Yadav, P.N.; Huang, X.P.; Feng, B.; et al. Discovery of beta-arrestin-biased dopamine D2 ligands for probing signal transduction pathways essential for antipsychotic efficacy. Proc. Natl. Acad. Sci. USA 2011, 108, 18488-18493. [CrossRef]

51. George, S.E.; Bungay, P.J.; Naylor, L.H. Functional analysis of the D2L dopamine receptor expressed in a cAMP-responsive luciferase reporter cell line. Biochem. Pharmacol. 1998, 56, 25-30. [CrossRef]

52. Klewe, I.V.; Nielsen, S.M.; Tarpo, L.; Urizar, E.; Dipace, C.; Javitch, J.A.; Gether, U.; Egebjerg, J.; Christensen, K.V. Recruitment of beta-arrestin2 to the dopamine D2 receptor: Insights into anti-psychotic and anti-parkinsonian drug receptor signaling. Neuropharmacology 2008, 54, 1215-1222. [CrossRef] [PubMed]

53. Frank, A.; Kiss, D.J.; Keseru, G.M.; Stark, H. Binding kinetics of cariprazine and aripiprazole at the dopamine D3 receptor. Sci. Rep. 2018, 8, 12509. [CrossRef] [PubMed] 
54. Xu, W.; Reith, M.E.A.; Chen, L.Y.; Kortagere, S. Biased signaling agonist of dopamine D3 receptor induces receptor internalization independent of beta-arrestin recruitment. Pharmacol. Res. 2019, 143, 48-57. [CrossRef]

55. Free, R.B.; Chun, L.S.; Moritz, A.E.; Miller, B.N.; Doyle, T.B.; Conroy, J.L.; Padron, A.; Meade, J.A.; Xiao, J.; $\mathrm{Hu}, \mathrm{X}$; ; et al. Discovery and characterization of a $\mathrm{G}$ protein-biased agonist that inhibits beta-arrestin recruitment to the D2 dopamine receptor. Mol. Pharmacol. 2014, 86, 96-105. [CrossRef]

56. Sautel, F.; Griffon, N.; Levesque, D.; Pilon, C.; Schwartz, J.C.; Sokoloff, P. A functional test identifies dopamine agonists selective for D3 versus D2 receptors. Neuroreport 1995, 6, 329-332. [CrossRef]

57. McDonald, W.M.; Sibley, D.R.; Kilpatrick, B.F.; Caron, M.G. Dopaminergic inhibition of adenylate cyclase correlates with high affinity agonist binding to anterior pituitary D2 dopamine receptors. Mol. Cell. Endocrinol. 1984, 36, 201-209. [CrossRef]

58. Sokoloff, P.; Andrieux, M.; Besancon, R.; Pilon, C.; Martres, M.P.; Giros, B.; Schwartz, J.C. Pharmacology of human dopamine D3 receptor expressed in a mammalian cell line: Comparison with D2 receptor. Eur. J. Pharmacol. 1992, 225, 331-337. [CrossRef]

59. Gao, Y.; Peterson, S.; Masri, B.; Hougland, M.T.; Adham, N.; Gyertyan, I.; Kiss, B.; Caron, M.G.; El-Mallakh, R.S. Cariprazine exerts antimanic properties and interferes with dopamine D2 receptor beta-arrestin interactions. Pharmacol. Res. Perspect. 2015, 3, e00073. [CrossRef]

60. Vanhauwe, J.F.; Fraeyman, N.; Francken, B.J.; Luyten, W.H.; Leysen, J.E. Comparison of the ligand binding and signaling properties of human dopamine $\mathrm{D}(2)$ and $\mathrm{D}(3)$ receptors in Chinese hamster ovary cells. J. Pharmacol. Exp. Ther. 1999, 290, 908-916.

61. Freedman, S.B.; Patel, S.; Marwood, R.; Emms, F.; Seabrook, G.R.; Knowles, M.R.; McAllister, G. Expression and pharmacological characterization of the human D3 dopamine receptor. J. Pharmacol. Exp. Ther. 1994, 268, 417-426. [PubMed]

62. Tadori, Y.; Forbes, R.A.; McQuade, R.D.; Kikuchi, T. Characterization of aripiprazole partial agonist activity at human dopamine D3 receptors. Eur. J. Pharmacol. 2008, 597, 27-33. [CrossRef] [PubMed]

63. Xu, W.; Wang, X.; Tocker, A.M.; Huang, P.; Reith, M.E.; Liu-Chen, L.Y.; Smith, A.B., III; Kortagere, S. Functional Characterization of a Novel Series of Biased Signaling Dopamine D3 Receptor Agonists. ACS Chem. Neurosci. 2017, 8, 486-500. [CrossRef] [PubMed]

64. Tang, L.; Todd, R.D.; Heller, A.; O’Malley, K.L. Pharmacological and functional characterization of D2, D3 and D4 dopamine receptors in fibroblast and dopaminergic cell lines. J. Pharmacol. Exp. Ther. 1994, 268, 495-502. [PubMed]

65. Slot, L.A.B.; Palmier, C.; Tardif, S.; Cussac, D. Action of novel antipsychotics at human dopamine D3 receptors coupled to $G$ protein and ERK1/2 activation. Neuropharmacology 2007, 53, 232-241. [CrossRef]

66. Vile, J.M.; D'Souza, U.M.; Strange, P.G. $\left[{ }^{3} \mathrm{H}\right]$ nemonapride and $\left[{ }^{3} \mathrm{H}\right]$ spiperone label equivalent numbers of D2 and D3 dopamine receptors in a range of tissues and under different conditions. J. Neurochem. 1995, 64, 940-943. [CrossRef]

67. Namkung, Y.; Dipace, C.; Urizar, E.; Javitch, J.A.; Sibley, D.R. G protein-coupled receptor kinase-2 constitutively regulates D2 dopamine receptor expression and signaling independently of receptor phosphorylation. J. Biol. Chem. 2009, 284, 34103-34115. [CrossRef]

68. Thal, D.M.; Yeow, R.Y.; Schoenau, C.; Huber, J.; Tesmer, J.J. Molecular mechanism of selectivity among G protein-coupled receptor kinase 2 inhibitors. Mol. Pharmacol. 2011, 80, 294-303. [CrossRef]

69. Lamey, M.; Thompson, M.; Varghese, G.; Chi, H.; Sawzdargo, M.; George, S.R.; O’Dowd, B.F. Distinct residues in the carboxyl tail mediate agonist-induced desensitization and internalization of the human dopamine D1 receptor. J. Biol. Chem. 2002, 277, 9415-9421. [CrossRef]

70. Pack, T.F.; Orlen, M.I.; Ray, C.; Peterson, S.M.; Caron, M.G. The dopamine D2 receptor can directly recruit and activate GRK2 without G protein activation. J. Biol. Chem. 2018, 293, 6161-6171. [CrossRef]

71. Namkung, Y.; Dipace, C.; Javitch, J.A.; Sibley, D.R. G protein-coupled receptor kinase-mediated phosphorylation regulates post-endocytic trafficking of the D2 dopamine receptor. J. Biol. Chem. 2009, 284, 15038-15051. [CrossRef] [PubMed]

72. Gurevich, E.V.; Gainetdinov, R.R.; Gurevich, V.V. G protein-coupled receptor kinases as regulators of dopamine receptor functions. Pharmacol. Res. 2016, 111, 1-16. [CrossRef]

73. Zhang, X.; Sun, N.; Zheng, M.; Kim, K.M. Clathrin-mediated endocytosis is responsible for the lysosomal degradation of dopamine D3 receptor. Biochem. Biophys. Res. Commun. 2016, 476, 245-251. [CrossRef] [PubMed] 
74. Pitcher, J.A.; Fredericks, Z.L.; Stone, W.C.; Premont, R.T.; Stoffel, R.H.; Koch, W.J.; Lefkowitz, R.J. Phosphatidylinositol 4,5-bisphosphate (PIP2)-enhanced G protein-coupled receptor kinase (GRK) activity: Location, structure, and regulation of the PIP2 binding site distinguishes the GRK subfamilies. J. Biol. Chem. 1996, 271, 24907-24913. [CrossRef] [PubMed]

75. Lieb, S.; Littmann, T.; Plank, N.; Felixberger, J.; Tanaka, M.; Schafer, T.; Krief, S.; Elz, S.; Friedland, K.; Bernhardt, G.; et al. Label-free versus conventional cellular assays: Functional investigations on the human histamine H1 receptor. Pharmacol. Res. 2016, 114, 13-26. [CrossRef] [PubMed]

76. Bartole, E.; Gratz, L.; Littmann, T.; Wifling, D.; Seibel, U.; Buschauer, A.; Bernhardt, G. UR-DEBa242: A Py-5-Labeled Fluorescent Multipurpose Probe for Investigations on the Histamine H3 and H4 Receptors. J. Med. Chem. 2020, 63, 5297-5311. [CrossRef]

77. Hübner, H.; Haubmann, C.; Utz, W.; Gmeiner, P. Conjugated Enynes as Nonaromatic Catechol Bioisosteres: Synthesis, Binding Experiments, and Computational Studies of Novel Dopamine Receptor Agonists Recognizing Preferentially the D3 Subtype. J. Med. Chem. 2000, 43, 756-762. [CrossRef]

78. Cheng, Y.; Prusoff, W.H. Relationship between the inhibition constant (K1) and the concentration of inhibitor which causes 50 per cent inhibition (I50) of an enzymatic reaction. Biochem. Pharmacol. 1973, 22, 3099-3108. [CrossRef]

(C) 2020 by the authors. Licensee MDPI, Basel, Switzerland. This article is an open access article distributed under the terms and conditions of the Creative Commons Attribution (CC BY) license (http://creativecommons.org/licenses/by/4.0/). 